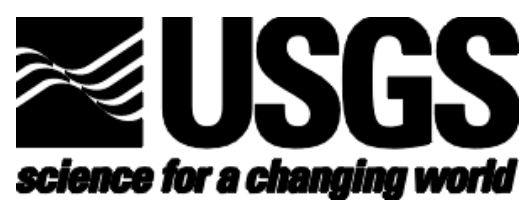

\title{
An Account of Preliminary Landslide Damage and Losses Resulting from the February 28, 2001, Nisqually, Washington, Earthquake
}

\author{
By Lynn M. Highland
}

This report is preliminary and has not been reviewed for conformity with U.S. Geological Survey editorial Standards or with the North American Stratigraphic Code.

Any use of trade, firm, or product names if for descriptive purposes only and does not imply endorsement by the U.S. Government.

Open-File Report 03-211

U.S. Department of the Interior

U.S. Geological Survey 


\section{CONTENTS}

Page

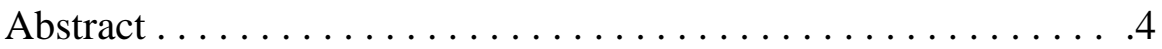

Introduction $\ldots \ldots \ldots \ldots \ldots \ldots \ldots \ldots \ldots \ldots$

General Information on Landslide Loss

Assessment Methodology .................. 5

Categories of Landslides . . . . . . . . . . . . . .5

Direct vs. Indirect Costs . . . . . . . . . . . 6

Public vs. Private costs . . . . . . . . . 7

The Complexity of Obtaining Accurate

and Complete Landslide Loss Data . . . . . . . . . . 7

Privacy Issues $\ldots \ldots \ldots \ldots \ldots \ldots \ldots \ldots \ldots$

Profile of the Nisqually Earthquake $\ldots \ldots \ldots \ldots \ldots \ldots \ldots 8$

Significant Landslides Caused by the

Nisqually Earthquake $\ldots \ldots \ldots \ldots \ldots \ldots \ldots$

Overview ................... 9

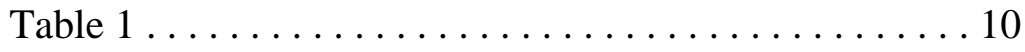

Figure $1 . \ldots \ldots \ldots \ldots \ldots \ldots \ldots \ldots \ldots \ldots \ldots \ldots \ldots \ldots$

Salmon Beach landslide . . . . . . . . . . . . . . .13

Cedar River Landslides, City of Renton . . . . . . . . 13

Capitol Lake/Deschutes Parkway ................14

Maplewild Avenue landslide, City of Burien . . . . . . . . 14

Tolmie State Park . . . . . . . . . . . . . . . . . 14 
Sunset Lake/Trosper Memorial Trailer Park,

Near Tumwater ....................... 15

U.S. Highway 101, Thurston County . . . . . . . . . 15

36th Street, West Seattle .................15

The Alaskan Way Viaduct ... . . . . . . . . . . . 15

Other Areas of Landslide Damage . . . . . . . . . . . . . 16

Other Highway Damage . . . . . . . . . . . . . . . . 17

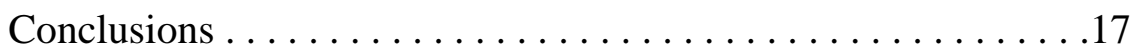

Recommendations for Future Study . . . . . . . . . . . . 18

Acknowledgements . . . . . . . . . . . . . . . 18

References ............................... . . . . .

APPENDIX A - Detailed Reports of Damage

Assessments . . . . . . . . . . . . . . . . 21

APPENDIX B - Preliminary Total Estimated Losses for the Nisqually

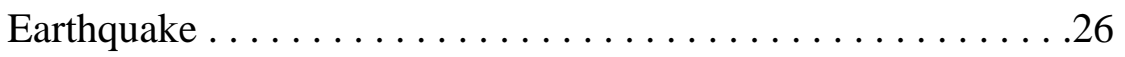

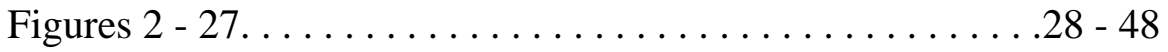




\begin{abstract}
$\underline{\text { Abstract }}$
The February 28,2001 , Nisqually, Washington, earthquake $\left(\mathrm{M}_{\mathrm{w}}=6.8\right)$ damaged an area of the northwestern United States that previously experienced two major historical earthquakes, in 1949 and in 1965. Preliminary estimates of direct monetary losses from damage due to earthquake-induced landslides is approximately $\$ 34.3$ million. However, this figure does not include costs from damages to the elevated portion of the Alaskan Way Viaduct, a major highway through downtown Seattle, Washington that will be repaired or rebuilt, depending on the future decision of local and state authorities. There is much debate as to the cause of the damage to this viaduct with evaluations of cause ranging from earthquake shaking and liquefaction to lateral spreading to a combination of these effects. If the viaduct is included in the costs, the losses increase to $\$ 500+$ million (if it is repaired) or to more than $\$ 1+$ billion (if it is replaced). Preliminary estimate of losses due to all causes of earthquake damage is approximately $\$ 2$ billion, which includes temporary repairs to the Alaskan Way Viaduct. These preliminary dollar figures will no doubt increase when plans and decisions regarding the Viaduct are completed.
\end{abstract}

\title{
$\underline{\text { Introduction }}$
}

The Nisqually Earthquake shook much of western Washington State on the morning of February 28, 2001, and caused widespread damage, much of which resulted from ground failure. This report presents a description and tabulation of damage and monetary losses caused by earthquake-induced landslides resulting from the earthquake. The Nisqually earthquake caused many types of ground failure, however, for the purposes of this study, only those instances that can be classified as landslides according to the movement types recognized by Cruden and Varnes (1996) will be noted. These include falls, topples, slides, spreads, flows, and combinations thereof. Liquefaction effects are not reported here, as they are generally considered an earthquake effect and not a landslide process. It should be noted that some areas experienced liquefaction and lateral spreads and other ground failures in close proximity.

Landslide inventories, locations, and some descriptions were taken from unpublished field notes provided by the Federal Emergency Management Agency (FEMA) and from unpublished reconnaissance reports of the United States Geological Survey (USGS). Both agencies had personnel in the field within one or two days of the earthquake, who performed thorough field inspections of earthquake and landslide effects. Additional information was provided by a National Science Foundation-sponsored unpublished report (Bray and others, 2001). Most unpublished information is currently on Internet sites that are referenced where applicable, throughout this report. However, long-term availability is uncertain, as many entities archive their Internet information onto different sites and addresses after certain lengths of time.

The USGS and FEMA supported this investigation with the goal of providing a framework for assessing future losses from earthquake-induced landslides as well as other types of landslides and as timely documentation of losses for future research. Loss assessment of natural hazard damage is a crucial aspect of the cost/benefit evaluations that are needed for mitigating landslide hazards. Losses due to landslides are not 
routinely compiled for most events, as they are difficult to ascertain for reasons cited later in this report.

As loss studies for landslides are so seldom performed, this report begins with a section on loss assessment methodology and definitions. Next, the earthquake is briefly described, along with the landslides it caused and their associated damages and costs. Appendix A includes a detailed description of landslide effects and monetary losses, and Appendix B presents a summary description of the total damage and losses from all effects of the Nisqually Earthquake.

All loss figures reported here are direct losses and do not include indirect losses, such as calculations of losses from business revenue due to landslide-damaged roadways. (Aspects of direct and indirect losses are discussed in the Loss Assessment Methodology section of this report.) All loss figures are preliminary and unless otherwise noted, have been converted to year 2002 dollars. These conversions were made using the Gross Domestic Product (GDP) Deflator Inflation index. This inflation calculation is based on the inflation rate during the US Government fiscal year, which begins on October 1 and ends on September 30.

The report is incomplete in the sense that some damage assessments are continually being evaluated and reassessed and have not been entirely completed for all areas. Some of the highway damage assessment is ongoing and changing, as differing repair and reconstruction scenarios continue to be evaluated by local officials. Financial losses reported here are necessarily preliminary and subject to change. It must also be noted that not all monetary losses have been reported because there are numerous privacy issues concerning some of the damage, and, as a result, data are unavailable.

\section{General Information on Landslide Loss-Assessment Methodology}

Landslide loss assessments are few and far between, as the reasons for their inherent difficulty are outlined as follows, in this section. However, there have been several successful efforts most notably those by Fleming and Taylor (1980) and by Schuster and Fleming (1986). This report is similar in approach to that detailed in Fleming and Taylor (1980).

\section{Categories of Landslide Loss}

Landslide-loss data are generally categorized as either direct or indirect. Other categories include losses suffered by public vs. private entities and whether the losses are insured or uninsured. Losses can occur to a geographic region collectively (many, possibly intermingled, landslides that may affect lifelines and public safety, as well as individual buildings) or as a single, isolated event that affects a small geographic area, such as a residential lot. 


\section{Direct vs. Indirect Costs}

Direct costs are the repair, replacement, or maintenance resulting from damage to property or installations within the boundaries of the responsible landslides or from landslide-caused flooding (Schuster, 1996). A good example of direct losses from a single major landslide is the Thistle, Utah, landslide of 1983. This 21-million cubic meter $\left(\mathrm{m}^{3}\right)$ landslide resulted in $\$ 200$ million dollars in direct damage (\$374 million, year 2001 dollars) (University of Utah, 1984). The landslide severed major transportation arteries, and the lake impounded and inundated the town of Thistle and railroad switching yards.

All other costs of landslides are indirect. Some examples of indirect landslide losses are:

1. Loss of industrial, agricultural, and forest productivity and tourist revenues as a result of damage to land or facilities or interruption of transportation systems;

2. Reduced real estate values in areas threatened by landslides

3. Loss of tax revenues on properties devalued as the result of landslides;

4. Measures that are required to be taken, to prevent or mitigate additional landslide damage;

5. Adverse effects on water quality in streams and irrigation facilities outside the landslide;

6. Loss of human or animal productivity because of injury, death, or psychological trauma; and

7. Secondary physical effects, such as landslide-caused flooding, for which losses are both direct and indirect.

Indirect costs may exceed direct costs; unfortunately, most indirect costs are difficult to evaluate and thus are often ignored or, when estimated, are too conservative.

The 1998 Anzar Road landslide which occurred during El Nino-driven storms in San Benito County, California is an excellent example of indirect losses, as well as direct losses. This landslide blocked a road, disrupted traffic, and damaged a house, causing losses which were directly due to the landslide itself - these losses are designated as direct losses. The same landslide broke a gas pipeline, which disrupted natural gas delivery to the city of Santa Cruz, California, shutting down many businesses for three days. This loss of business income, and the fact that the gas company had to relight all pilot lights in the city at great expense, is an example of indirect losses. The Anzar Road landslide is also a good example of the fact that losses from landslides are obtainable where entities involved are willing to share monetary information (Schuster and others, 1998). More often, however, monetary information, being of a discreet nature and in many instances, not public domain, people and entities prefer to leave their losses a private matter. 


\section{$\underline{\text { Public vs. Private Costs }}$}

Landslide losses also can be separated into categories of either public or private. Public costs are those that must be met by government agencies; all others are private costs. The largest direct public costs commonly have been for rebuilding or repairing governmentowned highways, railroads and structures such as sidewalks and storm drains. Other examples of direct public costs resulting from landslides are those for repair or replacement of public buildings, dams and reservoirs, canals, harbor and port facilities, and communications and electrical power systems. Indirect public costs include losses of tax revenues, reduction of potential for productivity of Federally managed forests, impact on quality of sport and commercial fisheries, and loss of user fees from affected areas such as National Parks and harbor and port facilities.

Private costs consist mainly of damage to real estate and structures, either private homes or industrial facilities. In the United States, most railroads are privately owned. Severe landslide problems can result in financial ruin for affected private property owners because of the general unavailability of landslide insurance or other means to compensate and distribute damage costs.

There are few instances of insured landslide losses, as most homeowner and commercial insurance does not cover landslides, or, the policies have prohibitively high-priced landslide riders with very high deductibles, so much so as to render them uneconomical to purchase. One exception is Federally subsidized flood insurance, but this type of insurance is available only to those who reside or hold property on Federally designated floodplains. Losses due to landslides or debris flows in conjunction with flooding are generally covered for holders of this type of insurance.

The Complexity of Obtaining Accurate and Complete Landslide Loss Data

Landslide-loss data are generally not tracked or published for several reasons. The lack of insurance for reimbursement does not encourage tracking or reporting. Damage due to landslides is not generally delineated in reports of flood, hurricane, or earthquake events and is usually combined with totals from these hazards; for example, landslide damage totals are not usually labeled separately from damage due to earthquake ground shaking. Thus, the impression is, that earthquake-induced landslides are not a significant concern when looking at damage totals from an earthquake. This is unfortunate, because in some cases, such as the 1964 Alaska earthquake, the primary damage was due to earthquake-induced landslides (Youd, 1978). Fortunately for reporting purposes, in the case of the Alaska earthquake, the damage was so devastating that the losses were described in detail. Hidden costs of landslide damage is common for floods and hurricanes. Landslide damage is not always described in detail in reports of damage assessments, but becomes lost in the flood accounts. This practice of generalizing and merging of cost data does not divulge an accurate picture of landslide impact in the United States.

Another reason landslide cost data are obscure is that cost data from landslide damage to highways, for instance, is often merged with general maintenance costs (such as road grading and clearing) in annual budget reports and these are not labeled or reported as 
damage due to landslides. There is at this time, no national reporting mechanism for landslide losses, and few states track landslide losses. There is also no uniform cost assessment methodology, as the entire approach is generally ad hoc however, Fleming and Taylor (1980) present a useful methodology, that characterizes a generally complete study. There is also no move afoot to combine and publish public and private landslide losses, as there are so many jurisdictions and no authority or incentive to merge these separate sets of data. There is also no current way of combining or reporting losses to property owners or developers when municipal planning or building departments designate property as too hazardous for building. These loss figures are often brought out in "takings" lawsuits filed by landowners and developers, but cost and loss data are rarely public domain, especially where out-of-court settlements take place.

Federal agencies, such as FEMA that are responsible for assessing and reimbursing (in some cases) losses from hazards, do not usually separate landslide losses from flood or earthquake events, for example. Those victims who apply for assistance from FEMA are required to describe damage in detail, and it is in these reports that details concerning landslides emerge. However, these reports are often difficult to find as they are couched in different departments of FEMA during and after FEMA responses to disasters. Other agencies concerned with disasters often publish loss statistics, but again, these statistics are usually composite totals, organized by jurisdiction, and not by exact cause of the loss.

The researcher relies on the largess of those individuals keeping track of losses and expenses, and their willingness to share information!

\section{$\underline{\text { Privacy Issues }}$}

Financial losses are a sensitive issue to many individuals and agencies, and there are considerations such as property values that come into play when reporting losses—or not reporting them. Many times, settlements for damages are anonymously transacted and any loss information is sealed in court documents. Such privacy concerns prohibit accurate loss assessments in many instances.

\section{Profile of the Nisqually Earthquake}

The Nisqually earthquake $\left(\mathrm{M}_{\mathrm{w}}=6.8\right)$ occurred in the Puget Sound area of western Washington on February 28, 2001. The event was similar in mechanism to the earthquakes of April 13, 1949 (Puget Sound earthquake; $M_{w}=7.1$ ) and the April 29, 1965 (Seattle earthquake; $M_{w}=6.7$ )(Bray and others, 2001). The epicenter is shown on the map in Figure 1. The Nisqually earthquake produced strong ground shaking over a wide area and caused damage in the Olympia, Seattle, and Tacoma areas of Washington. In all, 24 counties and 25 Indian reservations were included in a Presidential Disaster Declaration issued for the state on March 1, 2001 (Washington Emergency Military Department, 2002). One fatality is attributable to the earthquake and 400 persons sustained injuries. Observations of liquefaction were widespread in parts of Olympia and South Seattle, and several significant lateral spreads, embankment slides, and landslides occurred. The relatively long duration of the event and the relatively low cyclic resistance of some of the fills in the area are likely causes for the significant liquefaction 
and ground failure observed for this event (U.S. Geological Survey, unpub. data, 2001, [http://geohazards.cr.usgs.gov/wa/]).

\section{Significant landslides caused by the Nisqually earthquake}

\section{Overview}

Landslides triggered by the Nisqually earthquake were sparsely concentrated yet spread over a wide area. Due to the depth of the earthquake focus and the relatively low intensity of ground shaking, there appeared to be no dense concentration of landslides in any one area; however, the scattered failures that did occur have resulted in considerable impact to people and property. Many landslides occurred in the colluvial soils that mantle the slopes of the many hills in the lowland of Puget Sound; the number of these landslides was no doubt tempered by the unseasonably dry weather that preceded the earthquake (Nisqually Earthquake Clearinghouse Group, 2001). There were several instances of rock fall in the Puget Sound area. The most notable locations were Mount Si, (near North Bend); on the north side of Highway 410 both east and west of Skykomish; and at a steep road cut about $1 \mathrm{~km}$ east of LaGrande on Highway 7 (U.S. Geological Survey, unpub. data, 2001, [http://geohazards.cr.usgs.gov/wa/]). There was also a report of substantial rock fall activity in the crater at Mount St. Helens, Washington (Ed Klimasauskas, written commun., U.S. Geological Survey, February 28, 2001).

Table 1 presents location information and loss data on earthquake-induced landslides that were investigated by the Federal Emergency Management Agency (FEMA), Region X, Nisqually Earthquake Disaster Field Office, which was operational in Olympia, Washington, for several months after the earthquake occurred. Figure 1 shows geographical areas of these landslides based on Global Positioning System (GPS) latitude/longitude data obtained from FEMA and tabulated in Table 1. Some highway damage, as well as other smaller landslides and their accompanying dollar losses are not tabulated here, but are discussed in the text of this report. More detailed and itemized preliminary loss data for each landslide can be found in Appendix A. Note: Measurements are in units stated in the original source. Conversions to metric or standard measurements are inserted in parenthesis following the given measure. Descriptions of landslides on the following pages contain dollar losses in year 2001 dollars as designated in original references. 
Table 1.-Significant Nisqually earthquake-induced landslides. This table shows name of the landslide, location, preliminary dollar losses if obtained, and a short description. Tabular information is modified from a reconnaissance report by URS Corporation for FEMA Region X, Nisqually Earthquake Disaster Field Office (2001, unpub. data).

Table 1.-Significant Nisqually earthquake-induced landslides. This table shows name of the landslide, location, preliminary dollar losses if obtained, and a short description. Tabular information is modified from a reconnaissance report by URS Corporation for FEMA Region X, Nisqually Earthquake Disaster Field Office (2001, unpub. data).

\begin{tabular}{|c|c|c|c|}
\hline Landslide & $\begin{array}{l}\text { Landslide location: } \\
\text { Latitude/longitude } \\
\text { (where known) } \\
\text { City/County in } \\
\text { Washington }\end{array}$ & $\begin{array}{l}\text { Preliminary dollar } \\
\text { losses (where ob- } \\
\text { tainable) - in } \\
\text { year } 2002 \text { dollars }\end{array}$ & Comments \\
\hline Salmon Beach & $\begin{array}{l}47^{0} 17^{\prime} 52^{\prime}, \mathrm{N} \\
122^{0} 31^{\prime} 59^{\prime} \mathrm{W} \\
\text { Near Tacoma, } \\
\text { Pierce County }\end{array}$ & $\$ 1,505.428$ & $\begin{array}{l}\text { Steep, unstable } \\
\text { slope; slump } \\
\text { debris slide }\end{array}$ \\
\hline $\begin{array}{l}\text { Maple Valley/ } \\
\text { Cedar River }\end{array}$ & $\begin{array}{l}47^{0} 28^{\prime} 16^{\prime \prime} \mathrm{N} \\
122^{0} 08^{\prime} 47^{\prime} \mathrm{W} \\
\text { Near Renton, } \\
\text { King County }\end{array}$ & $\$ 1,714,400$ & $\begin{array}{l}\text { Soil fall from near- } \\
\text { vertical valley wall; } \\
\text { debris flow from } \\
\text { sand in fan, debris } \\
\text { dam in river }\end{array}$ \\
\hline $\begin{array}{l}\text { East side of } \\
\text { Capitol Lake } \\
\text { (Marathon Park)/ } \\
\text { Deschutes Park- } \\
\text { way }\end{array}$ & $\begin{array}{l}47^{0} 01^{\prime} 24 " \mathrm{~N} \\
122^{0} 533^{\prime} 54^{\prime \prime} \mathrm{W} \\
\text { Olympia, } \\
\text { Thurston County }\end{array}$ & $\$ 22,200,000$ & $\begin{array}{l}\text { Debris slide/flow into } \\
\text { Capitol Lake }\end{array}$ \\
\hline Maplewild Ave. & $\begin{array}{l}47^{0} 27^{\prime} 28^{\prime \prime} \mathrm{N} \\
122^{0} 22^{\prime} 03^{\prime \prime} \mathrm{W} \\
\text { Burien, } \\
\text { King County }\end{array}$ & $\$ 7,600,000$ & $\begin{array}{l}\text { Houses perched along } \\
\text { steep slope; slope } \\
\text { dropped several } \\
\text { inches; apparent } \\
\text { Structural damage }\end{array}$ \\
\hline Tolmie State Park & $\begin{array}{l}\text { Thurston } \\
\text { County }\end{array}$ & $\$ 384,000$ & $\begin{array}{l}\text { Structural damage } \\
\text { from lateral spreading }\end{array}$ \\
\hline $\begin{array}{l}\text { Trosper Sunset } \\
\text { Lake Mobile } \\
\text { Home Park }\end{array}$ & $\begin{array}{l}47^{0} 00^{\prime} 29^{\prime \prime} \mathrm{N} \\
122^{0} 54^{\prime} 55^{\prime \prime} \mathrm{W} \\
\text { Thurston County }\end{array}$ & $\begin{array}{l}\text { Losses not } \\
\text { obtained }\end{array}$ & $\begin{array}{l}\text { Lateral spreading; } \\
\text { sand boils }\end{array}$ \\
\hline
\end{tabular}


Table 1.-(cont.)

\begin{tabular}{|c|c|c|c|}
\hline Landslide & $\begin{array}{l}\text { Landslide location: } \\
\text { Latitude/longitude } \\
\text { (where known) } \\
\text { City/County in } \\
\text { Washington }\end{array}$ & $\begin{array}{l}\text { Preliminary dollar } \\
\text { losses (where ob- } \\
\text { tainable) - in } \\
\text { year } 2002 \text { dollars }\end{array}$ & Comments \\
\hline $\begin{array}{l}\text { U.S. Highway } 101 \\
\text { Near Sate Road } 8\end{array}$ & $\begin{array}{l}47^{0} 03^{\prime} 30^{\prime \prime} \mathrm{N} \\
123^{0} 00^{\prime} 49^{\prime \prime} \mathrm{W}\end{array}$ & $\$ 919,570$ & $\begin{array}{l}\text { Fill failure/slump; } \\
\text { debris flow }\end{array}$ \\
\hline $\begin{array}{l}\text { 36th Street, north } \\
\text { of SW Admiral } \\
\text { Way }\end{array}$ & $\begin{array}{l}47^{0} 34^{\prime} 56^{\prime \prime} \mathrm{N} \\
122^{0} 24^{\prime} \mathrm{W} \\
\text { West Seattle, } \\
\text { King County }\end{array}$ & $\begin{array}{l}\text { Losses not } \\
\text { obtained }\end{array}$ & $\begin{array}{l}\text { Movement beneath } \\
\text { road towards houses; } \\
\text { damage to pile } \\
\text { structures beneath } \\
\text { Houses }\end{array}$ \\
\hline \multirow[t]{2}{*}{$\begin{array}{l}\text { Alaskan Way } \\
\text { Viaduct }\end{array}$} & $\begin{array}{l}\text { Seattle, } \\
\text { King County }\end{array}$ & $\begin{array}{l}\text { Estimate one: } \\
\$ 500,500,000 \\
\text { Repairs to existing } \\
\text { Viaduct structure, } \\
\text { Plus cost of geo- } \\
\text { technical study, } \\
\text { which was } \\
\$ 500,000\end{array}$ & $\begin{array}{l}\text { Damage due to } \\
\text { presently un- } \\
\text { determined causes; } \\
\text { possible lateral } \\
\text { spreading, shaking; } \\
\text { liquefaction; most } \\
\text { likely a combination } \\
\text { of all }\end{array}$ \\
\hline & & $\begin{array}{l}\text { Estimate two: } \\
\$ 1,000,500,000 \\
\text { Replacement of } \\
\text { Viaduct plus cost } \\
\text { of geotechnical } \\
\text { study }\end{array}$ & $\begin{array}{l}\text { Repair vs. } \\
\text { Replacement scenario } \\
\text { is undecided as of } \\
\text { this writing }\end{array}$ \\
\hline
\end{tabular}




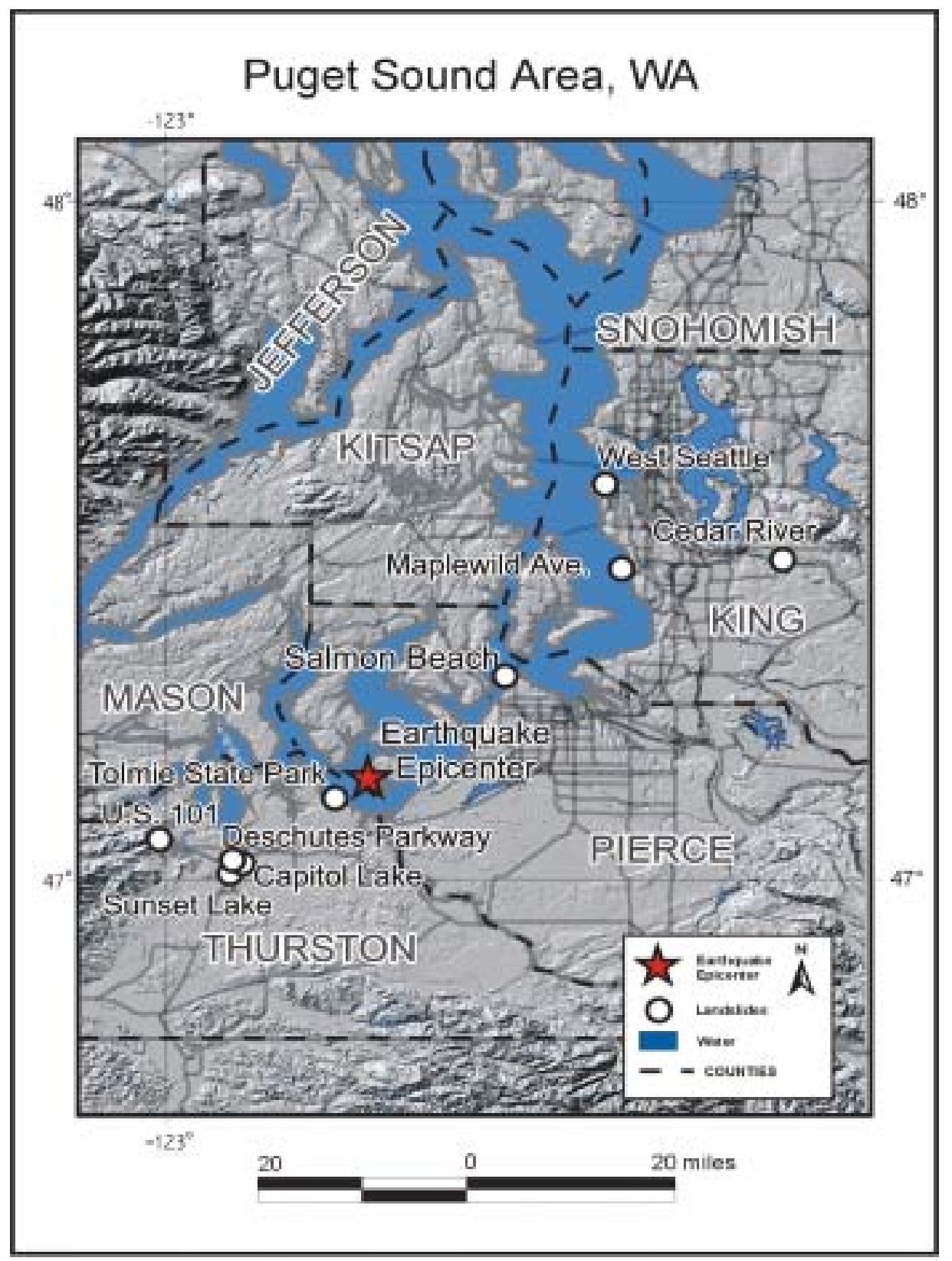

Figure 1-Puget Sound area, Washington-map of locations of significant landslides described in Table 1. Several minor occurrences of slumping and liquefaction are not shown, because they did not cause serious damage or any documented losses--they are discussed briefly in the text. (FEMA Region X, Nisqually Earthquake Disaster Field Office, 2001, unpub. data). 


\section{$\underline{\text { Salmon Beach landslide, near Tacoma }}$}

Salmon Beach, a community located north of the Tacoma Narrows bridge, near Point Defiance and Tacoma, Washington, was previously damaged by landslides that occurred as a result of the 1949 Puget Sound earthquake (Figure 2). Landslides occurred here again during the 2001 Nisqually earthquake and the Salmon Beach landslide is considered to be the landslide with the current highest hazard (Figure 3). This landslide was approximately 1,000 cubic meters (1,300 cubic yards) in volume, and demolished two houses (Figures 4 and 5) located at the base of the steep bluff along the shores of Puget Sound. A larger slide of about 10,000-20,000 cubic meters (13,000 to 26,000 cubic yards) of material remained poised on the slopes above the houses and threatened eight additional dwellings. This larger slide slid between 20 and 25 feet (6.6 and 8.3 meters) and has a scarp 20 to 25 feet (6.6 to 8.3 meters) high and approximately 20 feet (60 meters) in length along the top of the bluff. Eight houses were red-tagged as a result of inspection by Pierce County officials when notified of the existence of the larger landslide. Sewer, water, and electrical lines were also damaged by the landslide (Figures 6 and 7). Two homeowners associations that manage Salmon Beach and the city of Tacoma Public Utilities department (D. Koberstein, oral commun., 2001) have estimated total losses for the 2001 Salmon Beach landslide activity at \$1,505,428.

\section{Cedar River landslides - City of Renton}

The earthquake triggered failure of glacial deposits, estimated at 50,000 cubic yards (38,000 cubic meters), along the right bank of the Cedar River at River Mile 5.0 near the city of Renton. The landslide completely demolished 200 meters (200 yards) of King County's Punnett-Briggs Revetment, a public flood-erosion-control facility. This landslide blocked the Cedar River and created a reservoir until earth-moving equipment could be sent to the site and a ditch dug through the slide debris (Figures 8 and 9). Significant ponding and overbank flooding upstream of the blockage resulted in immediate flooding of two homes and several yards, together with significant portions of the City of Renton's Ron Regis Park (Figure 10). Impounded water in Ron Regis Park re-entered the river through a previously constructed salmon spawning channel adjacent to the landslide dam causing considerable erosion (King County Department of Natural Resources, oral commun., 2002).

In South Renton, a second landslide just upstream from the landslide that dammed the Cedar River formed at the base of a steep bluff. This mudflow carried about 10,000 cubic yards (7,600 cubic meters) of soil, trees and debris down to the Cedar River. The mudflow slammed into a house about 70 meters ( 70 yards) down slope nearly breaking it in two and filling about half of the structure with debris. A woman who had just run out of the house during the earthquake narrowly avoided being buried by landslide debris that filled the kitchen where she had been standing (Figure 11). Damage estimates for these landslides have been estimated to be $\$ 1,714,400$. (King County Department of Natural Resources, written commun., 2002). 


\section{Capitol Lake/Deschutes Parkway landslides}

Deschutes Parkway is underlain by fill, and artesian springs emerge within the fill. The Parkway is constantly failing and causing problems. During the earthquake, loose sandy soil under the Parkway liquefied, then flowed down slope toward Capitol Lake, collapsing part of the thoroughfare, and temporarily closing the road. This area had experienced similar lateral spreading and ground failures in the 1949 and 1965 Puget Sound earthquakes (Chleborad and Schuster, 1998). There was no way to put in an auxiliary or temporary road immediately after the failure. At the south end of the parkway, another landslide occurred 6 weeks after the earthquake. This damage will take approximately 3 years to repair -2 years to get permits and one year for construction, during which time the Parkway will be closed (T. Meade, Public Works Department, Olympia, Washington, oral commun. 2002).

Several lateral spread landslides occurred around the margins of Capitol Lake. The dike on the southern margin of the lake failed in several places; some of the cracks that formed contained ejected silt, indicating that liquefaction occurred. Water and sewer lines crossing the area were broken in places. Deschutes Parkway on the west margin of the lake was closed in several places because of slumping along the edge of the lake. (U.S. Geological Survey, unpub. data, 2001, [http://geohazards.cr.usgs.gov/wa/]). Estimated landslide damage to Capitol Lake, Marathon Park, and Deschutes Parkway was approximately $\$ 22,200,000$ (T. Meade, Public Works Department, City of Olympia, written commun., 2002). See Figures $12-18$ for photos of landslide and lateral spreading damage to these areas.

\section{Maplewild Avenue landslide, City of Burien}

Damage to Maplewild Avenue area occurred between 29th Place SW and 33rd Avenue SW. Five houses perched along a steep slope sustained structural damage when underlying uncompacted fill formed a translational slide during the earthquake. The area underwent several inches of vertical displacement (FEMA, unpub. data, 2001). The Federal Highway Administration has determined that Maplewild Avenue, being a Federal Arterial, is eligible for $\$ 6.6$ million in federal aid for repair and rebuilding. One house was demolished and sustained between $\$ 300,000$ and $\$ 400,000$ in losses. Two other houses suffered damages of $\$ 300,000$ total (Anonymous, City of Burien Dept. of Public Works oral commun., 2002). Maplewild Avenue, built in the 1930's, was extremely narrow and on a steep slope, and will be brought up to current Federal highway standards. City officials continue to work with homeowners who live in houses adjacent to the Maplewild Avenue right-of-way for repair to curb and driveways. Total losses sustained were approximately $\$ 7,600,000$.

\section{Tolmie State Park, Thurston County}

Tolmie Park, which is located 8 miles northeast of Olympia, is a day-use marine park with $600 \mathrm{~m}$ of saltwater shoreline bordering on Puget Sound. This 106-acre park is located 5 kilometers ( 3.1 miles) from the Nisqually Earthquake epicenter, and is visited annually by an average of 156,000 visitors, mainly between Memorial Day and Labor Day. All Sewer and water lines in the area were severely damaged, causing the 
temporary shutdown of the entire park. Bridges, trails, and a kitchen shelter were damaged by lateral spreading (Seattle Post-Intelligencer, 2001). Park officials suspect liquefaction as a contributing factor to the damage. The Federal Emergency Management Agency (FEMA) still requires a geological survey of the ground to see if it has stopped shifting, in order for repairs to begin, and damage estimates are to be finalized. Preliminary damage estimate for ground failure at Tolmie State Park is approximately $\$ 384,000$, if the shelter is replaced rather than repaired (Lynn Nordloh, Tolmie State Park Ranger, written commun., 2002).

\section{$\underline{\text { Sunset Lake - Trosper Memorial Trailer Park, near Tumwater }}$}

A lateral spread occurred around the perimeter road of Sunset Lake. This area also suffered other instances of lateral spreading, liquefaction, and sand boils, with damage to mobile homes (Bray and others, 2001) (Figures 19 and 20). Damage estimates were not available, at this writing, for this area.

\section{$\underline{\text { U.S. Highway 101, Thurston County }}$}

The northbound lanes of U.S. 101, near the junction with SR 8, west of Olympia slid away during the earthquake. A slump/debris flow about 15,000 cubic meters $(20,000$ cubic yards) in volume occurred in the artificial roadway fill of U.S. 101, removing one lane of the four-lane highway and flowing down slope between two houses before terminating on the surface of a street about $250 \mathrm{~m}$ down slope. Within 12 hours of the quake, Washington State Department of Transportation (WSDOT) maintenance workers constructed a detour roadway in the median area of the freeway and reopened the roadway to traffic in the northbound direction. Loss estimates are $\$ 919,570$. Work to restore the highway to its original condition was completed in August 2001 (Washington State Department of Transportation, 2002) (Figures 21-23).

\section{$\underline{36 \text { th Street, West Seattle }}$}

These landslides occurred on private property, with 10 homes affected, one property yellow-tagged by building officials. There were numerous cracks at the top of the slope (Oregon Department of Geology and Mineral Industries, 2001). The cost of damage was unavailable.

\section{$\underline{\text { The Alaskan Way Viaduct, Seattle }}$}

The Alaskan Way Viaduct, is a $3.36 \mathrm{~km}$-long double-deck, reinforced-concrete viaduct between Yesler Way and So. Washington Street in Seattle, Washington (Figure 24). It has supporting columns that currently are leaning up to $7.8 \mathrm{~cm}$ according to the Washington Department of Transportation. State inspectors discovered the eastward tilt during the first week after the earthquake. It appears that some tilt may have been present before the earthquake, and increased during the earthquake. There are several possible reasons for the leaning of the viaduct, according to Harvey Coffman, Bridge Engineer for Washington State Department of Transportation (WSDOT) ranging from lateral spreading, to liquefaction, and/or ground shifting. A $\$ 500,000$ study to determine whether to replace the viaduct or bring it up to current seismic standards is currently underway, and is expected to take at least 18 months. Speculation on costs of replacing 
the viaduct with an underground, ground level or elevated freeway run from $\$ 500$ million to $\$ 1$ billion, or more, and would take 10 years to complete.

The viaduct, completed in its entirety in 1956, did not include special reinforcing for earthquake resistance. Studies conducted by WSDOT in 1995-96 indicated that the Viaduct alignment is underlain by loose fill soils with a high susceptibility to liquefaction. It was concluded that widespread liquefaction would occur along the Viaduct in response to a peak ground acceleration of $0.16 \mathrm{~g}$. The study also indicated that widespread liquefaction would also likely result in failure of the Alaskan Way Seawall (adjacent to the viaduct) and massive lateral spreading of the adjacent soil. After the Nisqually earthquake, liquefaction features were observed in the South of Downtown district and the Harbor Island area of Seattle; however, none of these surface manifestations was observed beneath the viaduct, and there was no indication of failure of the Alaskan Way Seawall following the earthquake (WSDOT, 2001). One of the areas that sustained ground failure at the Alaskan Way Viaduct, is shown in Figure 24.

The Washington Department of Transportation (2001) Report of the Structural Sufficiency Committee recommends replacing the viaduct, because retrofitting it would cost about as much as replacement, and the resulting retrofitted structure would not last as long as a replacement. Currently there are several options for replacement. WSDOT and the City of Seattle are working together on the plans, since the adjacent seawall is owned by the City of Seattle and is a crucial structural element for replacement of the viaduct. Some of the replacement options are: replace in kind, replace with a tunnel, or replace with a boulevard.

As of April 2001, the Department of Transportation estimated that $\$ 62.71$ million in general costs would be required to repair roads, bridges, and ferry terminal facilities damaged in the earthquake (Wash Department of Transportation, 2002).

\section{Other Areas of Landslide Damage}

(Note: Loss figures are in year 2001 dollars as cited in original references)

The following list is not exhaustive, but includes some of the smaller landslides for which no damage figures were obtained.

1. King County Airfield - Serious cracking in runways due to liquefaction and lateral spreading (Washington State Emergency Military Department, 2002).

2. Seattle Harbor Island (consisting of a ferry terminal, ports, and a marina)-Experienced liquefaction, lateral spreading, and settlement (Oregon Department of Geology and Mineral Industries, 2001)

3. Chambers Creek Road, near Steilacoom, Pierce County- Ground failure was observed along the compacted earth embankments on both the upstream and downstream sides of a bridge on this road (Figure 25). A small landslide was observed adjacent to the western edge of the upstream abutment of the bridge a (Bray and others, 2001).

4. Pipeline Landslide- located at a pipeline right-of-way $2.4 \mathrm{~km}$ due east of Nulls Crossing (Lewis County), near Chahallis. The pipeline intersects a road at this point. It is 
possible that this slide was not triggered by the earthquake; however, the presence of newly fallen trees near the slide scarp may indicate that it was probably seismically induced (Bray and others, 2001) (Figure 26).

5. Burlington Northern/Santa Fe Railroad system reported losses of $\$ 200,000$ for repair of tracks, that were distorted by shifting and buckling, and possible lateral spreading (Gus Melones, Burlington Northern/Santa Fe Railroad Public Affairs Office, Seattle, Washington, written commun., 2001).

\section{Other Highway Damage}

1. Both lanes of State Route (SR) 302 at the north end of Case Inlet near the town of Allyn dropped 18 inches ( 0.5 meters) to 24 inches $(0.6$ meters) for a quarter of a mile ( 0.4 kilometer) through a landslide area (Bray and others, 2001).

2. State Road (SR) 202 near Snoqualmie Falls cracked and the shoulder fell away (Bray and others, 2001).

3. Victor Fill area near the City of Port Orchard experienced a slump in artificial fill. The vertical displacements of the highway along the slide scarp were as much as 60 centimeters (24 inches). Damage estimates are \$159,898, which includes temporary repairs, and restoration of the highway to service (Scott Woodruff, WSDOT, oral commun., 2001) (Figure 27).

4. A small slump buckled two lanes of Interstate 405 at 44th Street in Renton, raised the pavement and channeled water onto the freeway (Tom Baker, WSDOT, written commun., 2002,). The type of slide is unknown as of this writing.

\section{Conclusions}

Preliminary losses incurred by landslides induced by the Nisqually Earthquake totaled approximately \$34.3 million (year 2002 dollars) if the Alaskan Way Viaduct in Seattle is excluded. If damages from the viaduct are included, the total losses increase from a low range figure of $\$ 500,500,000$ (cost of geotechnical study and repairs to the existing Alaskan Way Viaduct) to a high of $\$ 1,000,500,000$ (replacement of portions of the viaduct), depending on the scenario the Washington Department of Transportation adopts for repair or repair/replacement of the viaduct, as discussed in the text. Ground failure occurring at the site of the Alaskan Way Viaduct has resulted in substantial damage, and these viaduct losses total up to one third or more of losses due to all effects of the Nisqually earthquake, which as of 2002, were estimated at approximately $\$ 2$ billion (excluding viaduct replacement).

Loss estimates do not include those that could not be obtained, including the Sunset Lake/Trosper Mobile Home Park landslide, the West Seattle landslide, and some of the smaller landslides. Future investigations and studies that revisit some of these sites, could possibly facilitate a more complete accounting of landslide losses. It cannot be emphasized enough that all of these figures will undoubtedly change as additional information is obtained, and final cost figures become available. See appendices A and B 
for additional information on the landslide loss and damage evaluations and loss figures for total losses and damages from all causes, for the Nisqually Earthquake.

\section{$\underline{\text { Recommendations For Further Study }}$}

It is the nature of landslide loss-figures that final totals may take years to assess and compile. It is commonly necessary to obtain a preliminary accounting of losses within a few months, and then to revise loss estimates at the end of the first year. Many loss assessments depend on engineering reports and other evaluations that may take a great deal of time.

It is also recommended that, where possible, losses be tallied as to type of loss by reporting agencies. For instance, it would be beneficial for future engineering studies for agencies such as FEMA to differentiate economic losses as to those from earthquake shaking, and those from landsliding and other ground failures. This differentiation is important because, as in the case for the Alaskan Way Viaduct, determination of whether the structure was damaged from shaking, liquefaction, lateral spreading, or a combination of factors, will affect future design criteria for repairs and/or reconstruction.

\section{$\underline{\text { Acknowledgements }}$}

The author would like to thank FEMA for their sponsorship of this investigation and especially Phillip Carpenter of the FEMA Region X Disaster Center, Olympia, Washington, for information on locations of landslides. Thanks also go to Edwin Harp, U.S. Geological Survey, for encouragement and support for this work. The author also expresses appreciation to officials of the Tacoma Public Utilities Department for providing loss information and and field assistance at the Salmon Beach landslide site. Many city and county officials throughout the Puget Sound area reported damage statistics; their cooperation and candor are acknowledged and appreciated 


\section{$\underline{\text { References }}$}

Bray, Jonathan D., Sancio, R. B., Kammerer, A. M., Merry, S.,

Rodriquez-Marek, A., Khazai, B., Chang, S., Hausler, E., Dreger, D., Perkins, W. J., and M. Nykamp, 2001, some observations of geotechnical aspects of the February 28, 2001, Nisqually earthquake in Olympia, South Seattle, and Tacoma Washington, web site report sponsored by the National Science Foundation, Pacific Earthquake Engineering Research Center, University of California at Berkeley, University of Arizona, Washington State University, Shannon \& Wilson, Inc., and Leighton and Associates. http://peer.berkeley.edu/nisqually/geotech

Chleborad, A., and R.L. Schuster, 1998. Ground failure associated with the Puget Sound Region earthquakes of April 13, 1949, and April 29, 1965: In Assessing earthquake hazards and reducing risk in the Pacific Northwest, Rogers, A.M., T.J. Walsh, W.J. Kockelman and G. J. Priest, eds., U.S. Geological Survey Professional Paper 1560, v. 2, pp. 373-439.

Cruden, D.L., and D.J. Varnes, 1996. Landslide types and processes, iㅡ Turner, A. Keith and Robert L. Schuster, eds., Landslides: investigation and mitigation, Transportation Research Board Special Report 246, National Research Council, National Academy Press, Washington, D.C., pp. 36-75.

Fleming, Robert W., and Fred A. Taylor, 1980. Estimating the Costs of Landslide Damage in the United States, U.S. Geological Survey Circular, 832, 21 p.

Nisqally Earthquake Clearinghouse Group, 2001. The Nisqually, Washington, Earthquake of February 28, 2001, Preliminary Reconnaissance Report, Earthquake Engineering Research Institute, EERI Publication No. 2001-01, Oakland, CA. A report sponsored by NSF, FEMA, and the University of Washington, Seattle.

Oregon Department of Geology and Mineral Industries, 2001. February 28, 2001 Nisqually, Washington, earthquake summary report, Portland, Oregon. http://www.oregongeology.com/nisquallyGLFolder/Mei2Nisqually.htm

Schuster, Robert L., Baum, Rex L., and Lynn M. Highland, 1998. The April 1998 El Niño-triggered Anzar Road Landslide, San Benito County, California, AEG News, Vol. 41, No. 4, Association of Engineering Geologists.

Schuster, Robert L. 1996. Socioeconomic significance of landslides, in Turner, Keith and Robert L. Schuster, eds. 1996. Landslides: investigation and mitigation, Transportation Research Board Special Report 247, National Research Council, National Academy Press, Washington, D.C., pp. 3-35 
Schuster, R.L., and R.W. Fleming, 1986. Economic losses and fatalities due to landslides, Bulletin of the Association of Engineering Geologists, Vol. 23, No. 1, pp. 11-28, Vol. 23, No. 1, pp. 11-28.

Seattle Post-Intelligencer, 2001, Seattle, Washington, March 30.

University of Utah, 1984. Flooding and Landslides in Utah-An Economic Impact Analysis. University of Utah Bureau of Economic and Business Research, Utah Department of Community and Economic Development, and Utah Office of Planning and Budget, Salt Lake City, 123 p.

Washington State Department of General Administration, 2002. Downtown Olympia Improvement Projects, May, 2002, Public Works Department, City of Olympia.

Washington Emergency Military Department, 2002, Nisqually Earthquake one-year anniversary, in Regional Public Information Network, Regional Newsletter, Report of the Washington Military Department, Emergency Management Division Annual Report, February 25. http://emd.wa.gov/4-pio/archive/02-archive/020102.pdf

Washington State Dept. of Transportation, 2001. Alaskan Way Viaduct-Report of the Structural Sufficiency Review Committee, prepared by T.Y. Lin International, 37 p., Report of Committee of Independent Engineers

Washington State Department of Transportation, 2002. WSDOT News, February 21, 2002, http://www.wsdot.wa.gov/news/earthquake/default.htm.

Youd, T.L., 1978, Major cause of earthquake damage is ground failure: Civil Engineering, v. 48, no. 4, pp. 47-51. 


\section{$\underline{\text { Appendix A }}$}

\section{Detailed Reports of Damage Assessments}

Appendix A contains detailed descriptions and notes of preliminary monetary losses from each of the landslide occurrences, discussed in the body of this report. In some instances, losses are itemized where information was available. Loss figures are given in year 2001 or 2002 dollars as reported in original references. It should be noted that many figures may be preliminary, and may be updated and/or changed. In addition, Appendix A includes a complete list of entities consulted for information on damages and losses for the Nisqually earthquake.

\section{$\underline{\text { Salmon Beach landslide }}$}

This information is updated information from Tom Bentson, City of Tacoma, Washington, personal communication on September 4, 2002.

- The Salmon Beach Community boardwalk was destroyed by the landslide and needed replacement $-30 \mathrm{~m}$ of boardwalk was damaged. Replacement cost is $\$ 40-\$ 60$ per meter, which totals $\$ 72,000$.

- The estimate from a geotechnical consulting company (unnamed) for slope re-grading in landslide area is $\$ 325,000$.

- The damage to the sanitary sewer line is $\$ 20,000$; the cost to bury the line is $\$ 20,000$, for a total of $\$ 40,000$ damage. This was a temporary fix, not a permanent solution.

The line will be buried along hillside trail to top of slope (residential parking area)

- Tacoma Power and Light, an electrical provider, performed temporary wiring and replacing of electrical wires and poles at a cost of $\$ 40,000.00$.

- As a more permanent solution, replacement of wiring infrastructure was performed at an additional $\$ 20,000.00$ This action placed power poles on the base of the slope, onto the flat part of the beach.

- Damage to Click! Network (Cable T.V. company) was estimated at $\$ 5,000.00$

- Two homes destroyed by landslide sustained a combined loss of $\$ 425,000.00$ Note: homeowners rebuilding residences are required to purchase flood insurance in order to get new building permits, so whatever the cost of insurance counted as a loss in this instance. Total cost of the insurance is unknown at this writing and is an indirect loss.

- Repairs to other houses damaged by landslides from Nisqually Earthquake (Personal communication, 2002, Mary Hopkins, president of one of the two Salmon Beach Homeowners Associations)

1. $\$ 4,000$

2. $\$ 628$

3. $\$ 4,000$

4. $\$ 4,800$ 
- There was damage to five homes' water supply catchment systems at $\$ 1,000$ each, for a total of $\$ 5,000$.

- The estimated replacement cost of sewer system for Salmon Beach, (a better, more permanent solution than repair of the old one) is estimated to be $\$ 600,000.00$ (John Stetson, City of Tacoma, written commun., 2001). An application to FEMA for such a system is in process.

\section{Maple Valley/Cedar River}

City of Renton estimates damages of $\$ 982,400.00$ for damage to the Cedar River spawning channel as a result of the earthquake-induced landslide. Damage assessment was submitted to FEMA for possible reimbursement (Lys Hornsby, City of Renton, Washington, written commun., 2001,)

- A house on Cedar River, near Renton, was damaged from flooding resulting from one of the landslides which temporarily blocked the river. The damage to the house was estimated to be approximately $\$ 170,000$.

- Damage to the Punnett/Briggs Revetment is estimated at $\$ 350,000$. An application for reimbursement of damages has been submitted to FEMA (Ken Zweig, City of Renton, Washington, 2002, oral commun.).

- The repairs and stabilization of the second of the two landslides that occurred are approximately $\$ 212,000$ (Anonymous, King County, Washington, Department of Natural Resources, written commun., 2002).

- Losses for Maple Valley/Cedar River total \$1,714,400.

\section{Capitol Lake/Deschutes Parkway, Olympia}

- Landslide and lateral-spreading damage to the Deschutes Parkway: the City of Olympia has submitted a claim of $\$ 20$ million to Federal Highways Administration.

Deschutes Parkway repair and re-design will be part of a long-term project to stabilize the highway and to prevent damage from future earthquakes. The 1.6-mile long parkway will be repaired and upgraded with an asphalt-concrete surface, new storm water drainage, and new wastewater pipelines (Washington State Department of General Administration, 2002).

- Damage to Capitol Lake and Marathon Park totals $\$ 600,000$. There was also damage to the Interpretive Center, totaling $\$ 300,000$ (City of Olympia, Washington, written commun, 2002.) 
- Losses amounted to $\$ 1,300,000$ for damage to nearby six streets, located near Deschutes Parkway. (Tom Meade, Public Works Department, City of Olympia, Washington, written commun., 2002).

\section{Maplewild Avenue, Burien}

The Federal Highway Administration has determined that Maplewild Avenue, being a Federal Arterial is eligible for the $\$ 6.6$ million for repair and rebuilding. The road, built in the 1930's was extremely narrow and on a steep slope, will be brought up to current Federal standards. Four houses in the vicinity of Maplewild Avenue sustained damages. One house was demolished and sustained between $\$ 300,000$ and $\$ 400,000$ in losses, and the homeowner's earthquake insurance paid to replace the house. Two other houses suffered damages of $\$ 300,000$ total (Anonymous, City of Burien, Washington, written commun., 2002). No information on the fourth house could be obtained.

\section{Tolmie State Park}

Tolmie State Park was subjected to lateral spreads and liquefaction. A final geotechnical report will be forthcoming in the near future. The losses as of this writing, are outlined as follows.

Damages and estimated losses for Tolmie Park:

Debris clean up

Signs and security

Sewer system repairs

Repairs to roads

Repairs to pedestrian bridges

Broken water lines

Repairs to lower kitchen shelter (if shelter cannot be fixed in place, it will have to be relocated)

Total

Total if shelter needs to be replaced
$\$ 1,000$

3,000

20,000

80,000

15,000

15,000

80,000

Loss and repair data was obtained from Maintenance Preservation Manager for the Southwest Region, Washington State Parks, Lynn Nordloh, (written commun., May 5 , 2002).

Sunset Lake - Tumwater Memorial Mobile Home Park, Tumwater Damages figures not obtained 


\section{U.S. Highway 101, near State Road 8, Thurston County}

Losses for this area include $\$ 195,125$ for maintenance repairs and $\$ 264,660$ contract work for additional repairs.

Funding source:

Maintenance, $\$ 177,125$, federal emergency relief; $\$ 18,000$ in state funds

Contract work: $\$ 264,660$ federal emergency relief

(Data is from Washington State Department of Transportation, WSDOT News, February

21, 2002, [http://www.wsdot.wa.gov/news/earthquake/default.htm].

West Seattle, $36^{\text {th }}$ Street, Seattle

No loss data available at this writing - damages occurred on private property.

\section{Other Highway/Transportation Damage}

1. Both lanes of state Route 302 at the north end of Case Inlet near Allyn dropped 18 to 24 inches ( 0.5 to 0.66 meter)

2. Burlington Northern/Santa Fe Railroad

Estimated track repairs, in the Nisqually area were approximately $\$ 200,000$, due to shifting buckling damage. (Gus Melones, Director of Public Affairs for Burlington Northern/Santa Fe Railroad, oral commun., 2002). Mr. Melones also stated that normal operations dictate that in the event of a 5.0 M earthquake, ALL operations are shut down for a $200-$ mile $(320-\mathrm{km})$ radius, which is what happened during the Nisqually earthquake. Fifteen trains were shut down, including AMTRAK. The total cost of the shutdown was unavailable as of this writing, and is classified as an indirect loss.

Entities and Agencies Contacted to Determine Damages and Losses

1. Federal Emergency Management Agency (FEMA) Region X

2. Small Business Association

3. Indian tribes

4. Burlington Northern/Santa Fe Railroad

5. City of Renton

6. City of Olympia

7. City of Bremerton

8. City of Tacoma

9. City of Seattle

10. Clallam County

11. Skagit County

12. Cowlitz County

13. Thurston County

14. Pierce County

15. Snohomish County

16. Grays Harbor County

17. Kitsap County 
18. Lewis County

19. Mason County

20. King County

21. Pacific County

22. City of Tumwater

23. Washington Department of Transportation (WSDOT)

24. Tolmie State Park, Thurston County

25. City of Burien

26. Salmon Beach (Tacoma) homeowners associations

27. University of Washington

28. Washington State Military Department, Emergency Management Division

29. Nisqually Earthquake Clearinghouse - University of Washington, Seattle http://www.ce.washington.edu/ nisqually/

30. Seattle Post Intelligencer

31. Shannon and Wilson, Inc., Seattle, Washington

32. EQE International, Seattle, Washington

33. Golder Associates, Redmond, Washington

34. GeoEngineers, Redmond, Washington

35. The Boeing Company

36. Seattle School District

37. U.S. Department of Transportation

38. Port of Seattle

39. Sea-Tac Airport

40. Confederated Tribes of the Chehalis Reservation

41. King County Airfield (Boeing Field) 


\section{$\underline{\text { Appendix B }}$}

\section{TOTAL ESTIMATED LOSSES FOR THE NISQUALLY EARTHQUAKE}

(Note: Costs are presented in year 2001 dollars as originally cited)

The following information is compiled in "Report of the Washington Military Department, Emergency Management Division, 2001 Annual Report." It is a comprehensive overview of significant effects of the Nisqually Earthquake, to the Puget Sound, Washington region. This report is currently archived on the agency website (see references).

Six counties in the Puget Sound area, King, Kitsap, Lewis, Mason, Pierce, and Thurston were the most severely damaged by the Nisqually earthquake and were declared Federal disaster sites, making them eligible to receive federal funding for recovery through both public assistance and individual assistance grants. Thirteen counties, Clallam, Cowlitz, Grays Harbor, King, Kitsap, Lewis, Mason, Pacific, Pierce, Skagit, Snohomish, Thurston, and Whatcom, have been declared for both public assistance and individual assistance. Nine counties, Benton, Chelan, Clark, Island, Jefferson, Kittitas, Skamania, Wahkiakum, and Yakima have been declared for individual assistance only; and two-Douglas and Walla Walla—have been declared for public assistance only.

Indian tribal governments eligible for public assistance and individual assistance funding included the Confederated Tribes of the Chehalis Reservation, Jamestown S'Kallam Tribe, Lower Elwha, Lummi Nation, Makah Tribe, Muckleshoot Tribe, Nisqually Tribe, Nooksack Tribe, Port Gamble Indian Community, Puyallup Tribe, Quileute Tribe, Quinault Tribe, Samish Nation, Sauk-Suiattle Tribe, Shoalwater Bay Tribe, Skokomish Tribe, Snoqualmie Tribe, Squaxin Island Tribe, Stillaguamish Tribe, Suquamish Tribe, Swinomish Tirbe, Tulalip Tribe, and the Upper Skagit Tribe. The Hoh Tribe and the Yakama Nation were eligible for individual assistance only. All tribal governments in the state are eligible for hazard mitigation assistance. The Seattle power company, Seattle City Light reported 17,000 customer power outages; Puget Sound Energy reported 200,000 power outages.

There was minor structural damage reported to water utilities in this area, and only one gas line leak reported.

Several government buildings in Olympia, including the capitol, were significantly damaged. The 74 year-old capitol dome sustained a deep crack in its limestone exterior and damage to supporting columns. Additional non-structural damage areas throughout the building.

Transportation systems suffered extensive damage. There was serious damage to the region's largest airports; Seattle-Tacoma International Airport was immediately closed because the control tower was disabled. The tower suffered both structural and nonstructural damage. The King County Airport (Boeing Field) suffered serious cracking and gaps on the runway due to soil liquefaction and lateral spreading. Several state 
routes and local roadways were closed due to slumping and pavement factures. Two bridges were closed because of significant damage - the Magnolia Bridge in Seattle and the 4th Avenue Bridge in Olympia. Although damage to most other bridges was minor, additional earthquake damage has been discovered on SR 99, the Alaskan Way Viaduct, a major arterial in Seattle. Dock facilities in both Tacoma and Seattle sustained minor damage.

Of the 290 non-federal dams inspected by state engineers, only five were found to have sustained earthquake-related damage. The five dams that were damaged were all poorly constructed dams on weak foundations. No earthquake related-damage was found at the dams in the state that are controlled or regulated by the Federal Energy Regulatory Commission (FERC), the Bureau of Reclamation, or the U.S. Army Corps of Engineers.

Building damage varied widely throughout the region. Seattle's historic Pioneer Square District and downtown Olympia were hit hard. Un-reinforced brick masonry buildings with un-braced parapets no wall anchors were particularly vulnerable, resulting in several collapses. Throughout the impacted area, over a thousand buildings were either redtagged or yellow-tagged for inspection. While severe structural damage to businesses was relatively limited, non-structural damage, and the associated business disruption, caused significant economic loss.

Damage to residences came in a variety of forms, from severe landslide destruction of entire houses to breakage of replaceable personal property. The most common damage was to chimneys. FEMA records indicate that one-third of the 30,000 homes inspected by FEMA sustained chimney damage. Significant home damage was due to road and foundation failures in a Nisqually-area mobile-home park and the Sunset Lake Mobile Home Park in Tumwater, landslides at Salmon Beach near Point Defiance in Tacoma; and landslides and flooding in Maplewood near Renton, Washington.

A total of 41,411 people registered with FEMA for this agency's Individual Assistance, the largest number in the state's disaster history. These people have received almost \$56 million in rental assistance and minimal repair grants from FEMA, \$15 million of which was applied toward chimney damage. More than $\$ 3.3$ million has been approved through the Individual and Family Grant Program. The U.S. Small Business Administration has approved 6,245 loans, totaling more than $\$ 83$ million.

The Public Assistance Program serving public, certain non-profit, and Indian tribes estimated that $\$ 75$ million was awarded for eligible infrastructure repairs.

FEMA's Hazard Mitigation Grant Program estimated \$21,200,000 was available for mitigation projects statewide.

Updated reports:

As of April 2001, the U.S. Department of Transportation estimated a total of $\$ 62.71$ million in general costs to repair roads, bridges and ferry facilities damaged in the earthquake. 


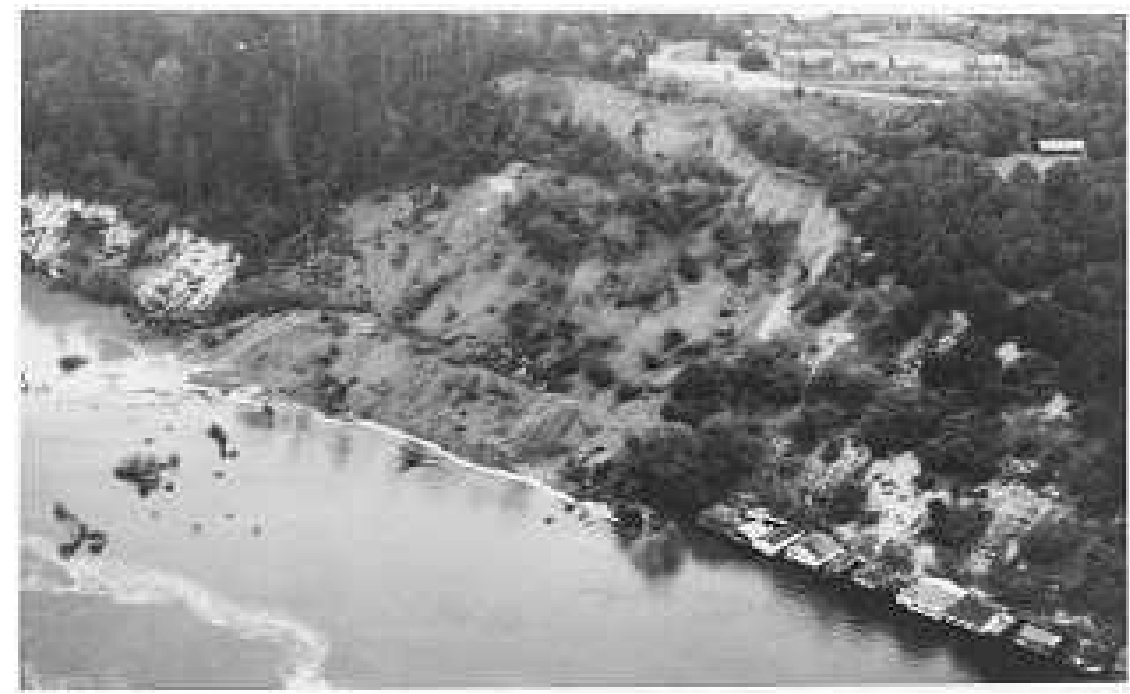

Figure 2-Salmon Beach, near Tacoma, Washington area after the 1949 Puget Sound earthquake (Photo by Associated Press).

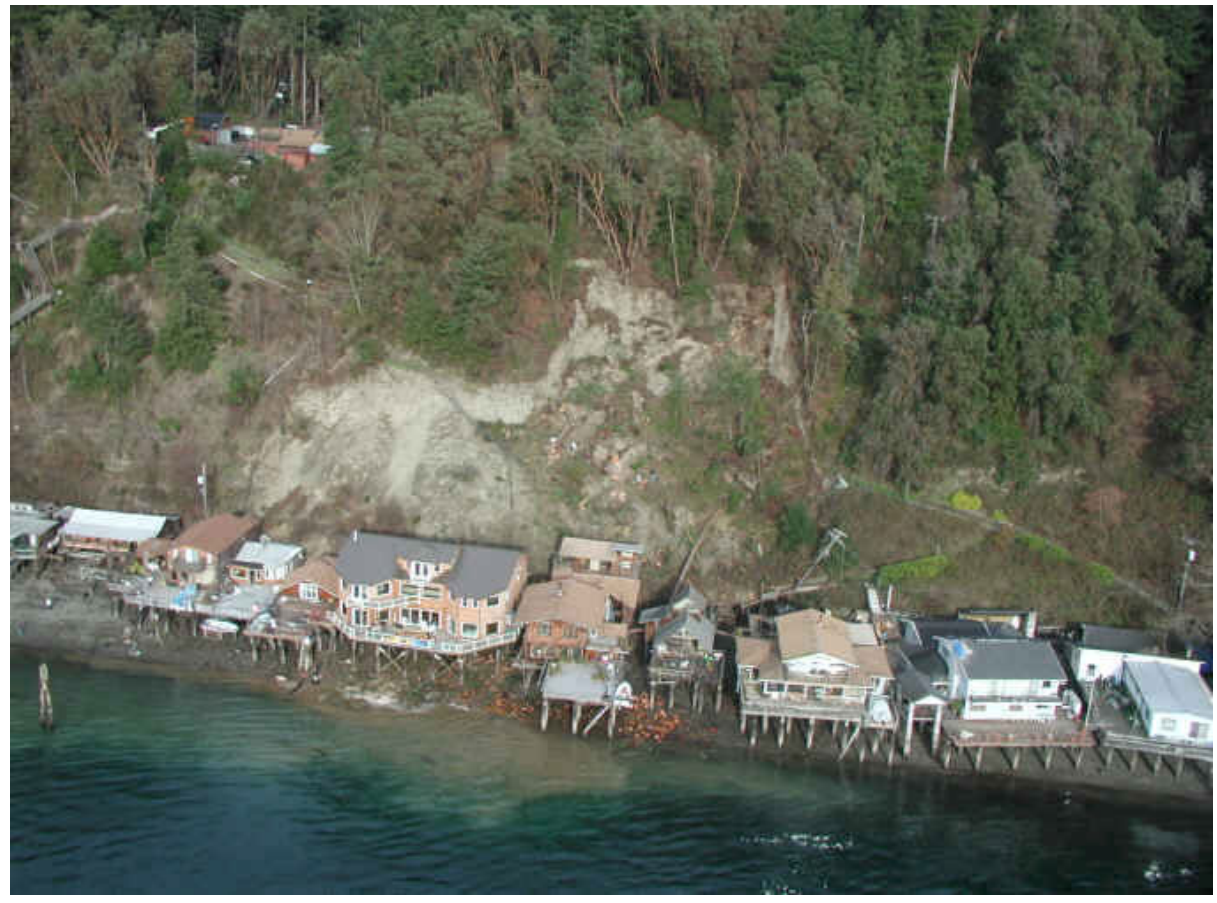

Figure 3-Salmon Beach landslide area, near Tacoma, after the 2001 Nisqually earthquake. Puget Sound is in the foreground (Photo from Bray and others, 2001) 


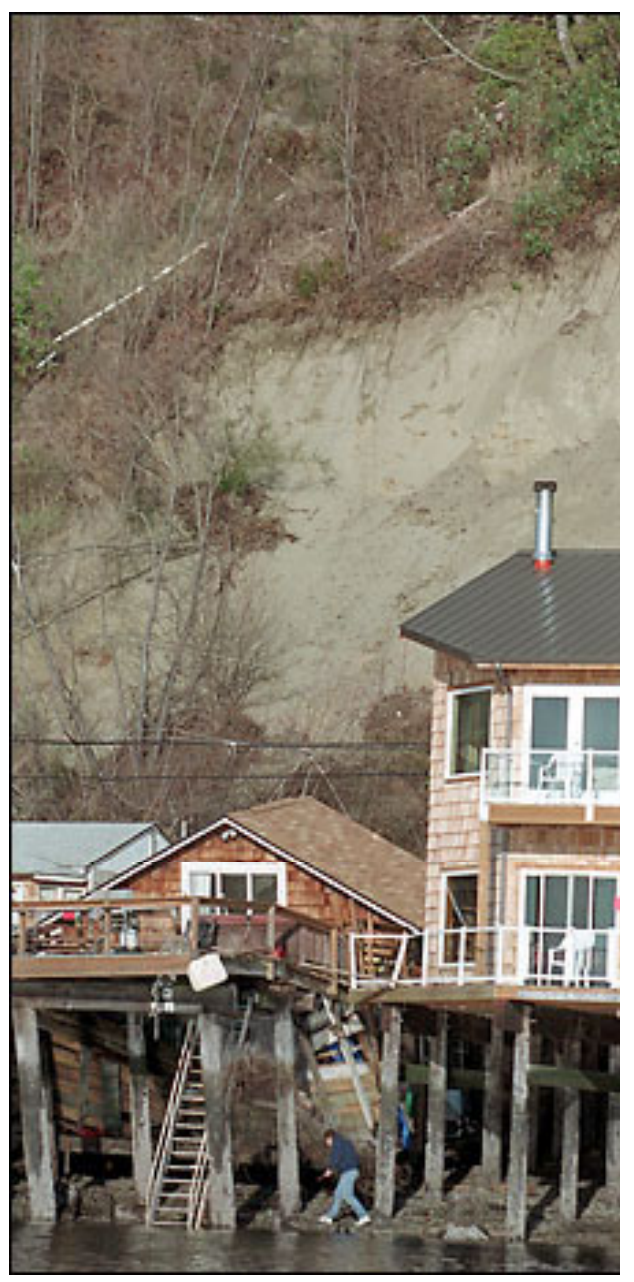

Figure 4-Close-up photo of one of the Salmon Beach houses damaged by a landslide, shortly after the Nisqually earthquake occurred (Photo courtesy of The Seattle Times). 


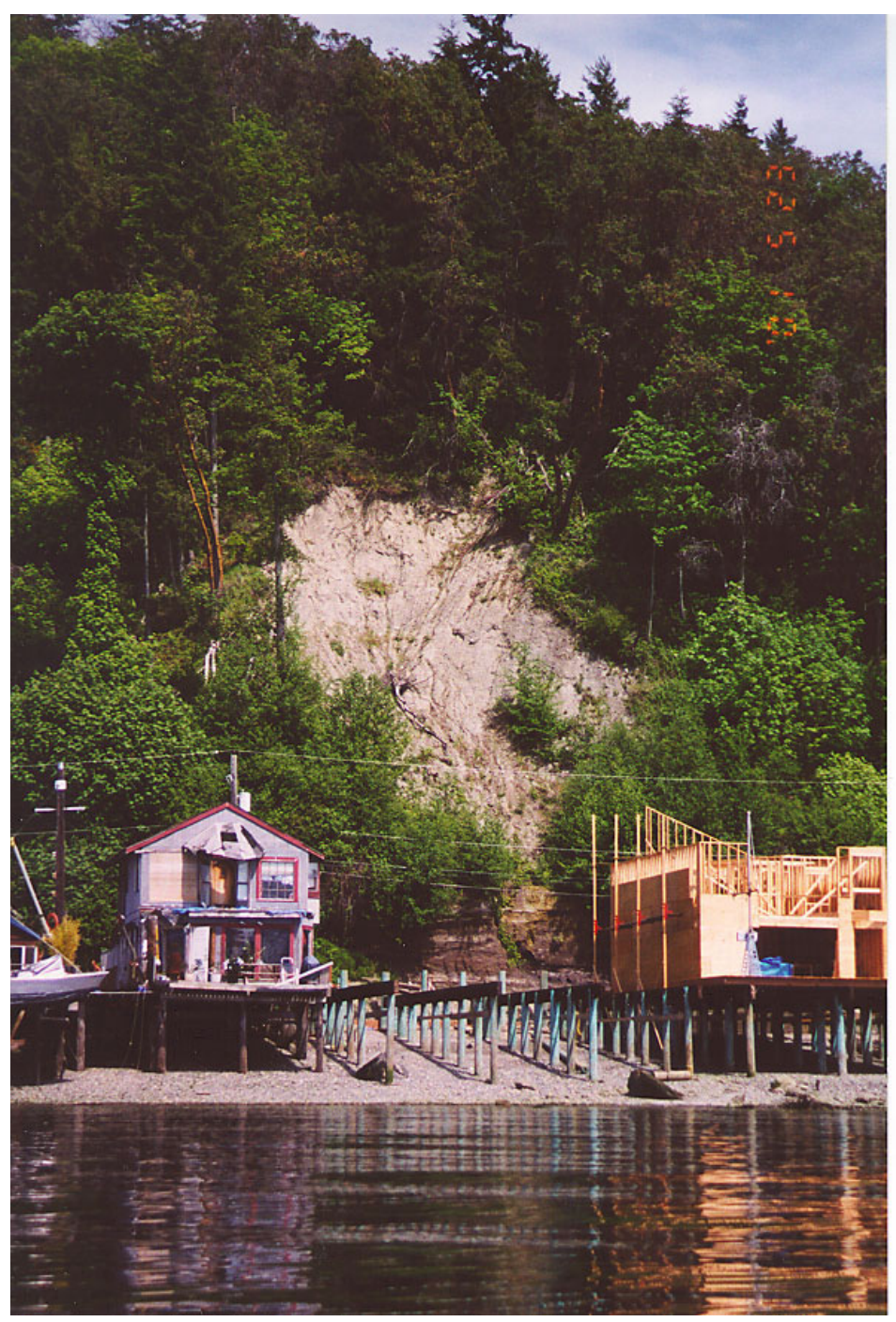

Figure 5-Salmon Beach house, destroyed by landslide. The house was damaged and then was torn down. The house under construction to the right, is being rebuilt, as it was also destroyed by the landslide (Photo taken in June, 2001 by Lynn Highland, USGS). 


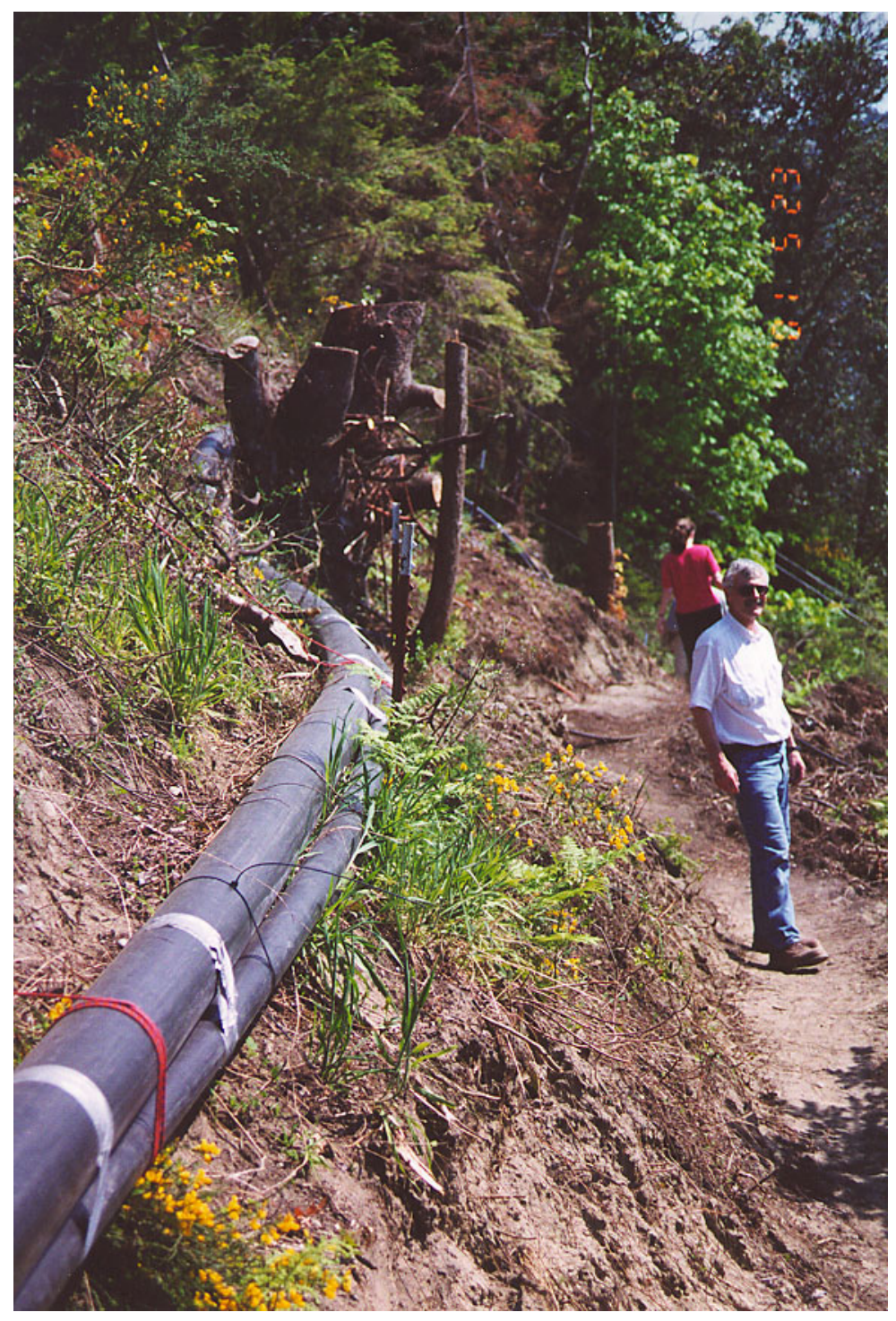

Figure 6-water and sewer line, temporarily relocated on top of landslide material, Salmon Beach landslide.

Original sewer and water lines were damaged by the slide (Photo taken in June, 2001 by Lynn Highland, USGS). 


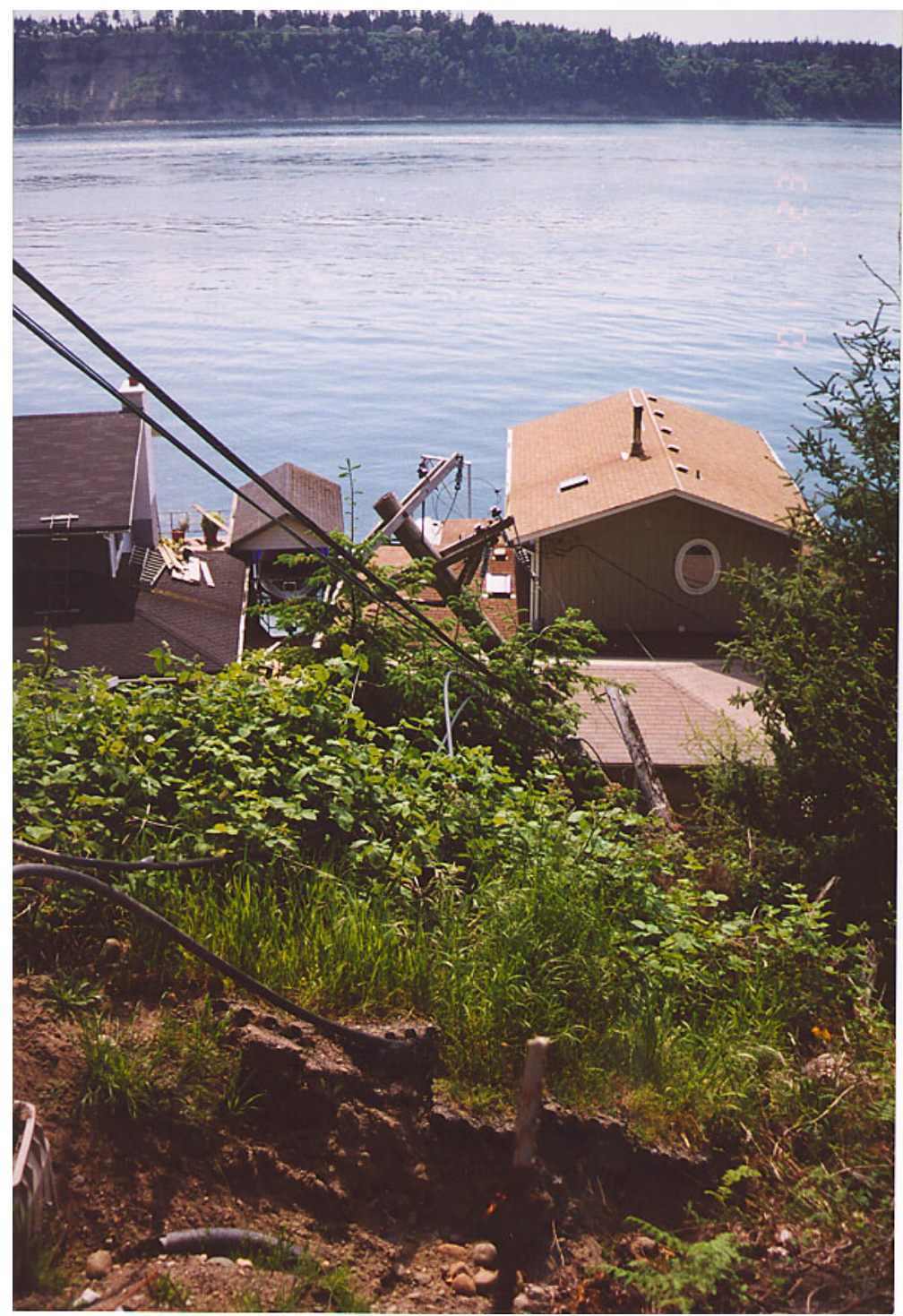

Figure 7-Looking toward Puget Sound from the Salmon Beach landslide. The landslide damaged elecritical utility poles and electrical lines in the Salmon Beach community (Photo taken June, 2001 by Lynn Highland, USGS). 


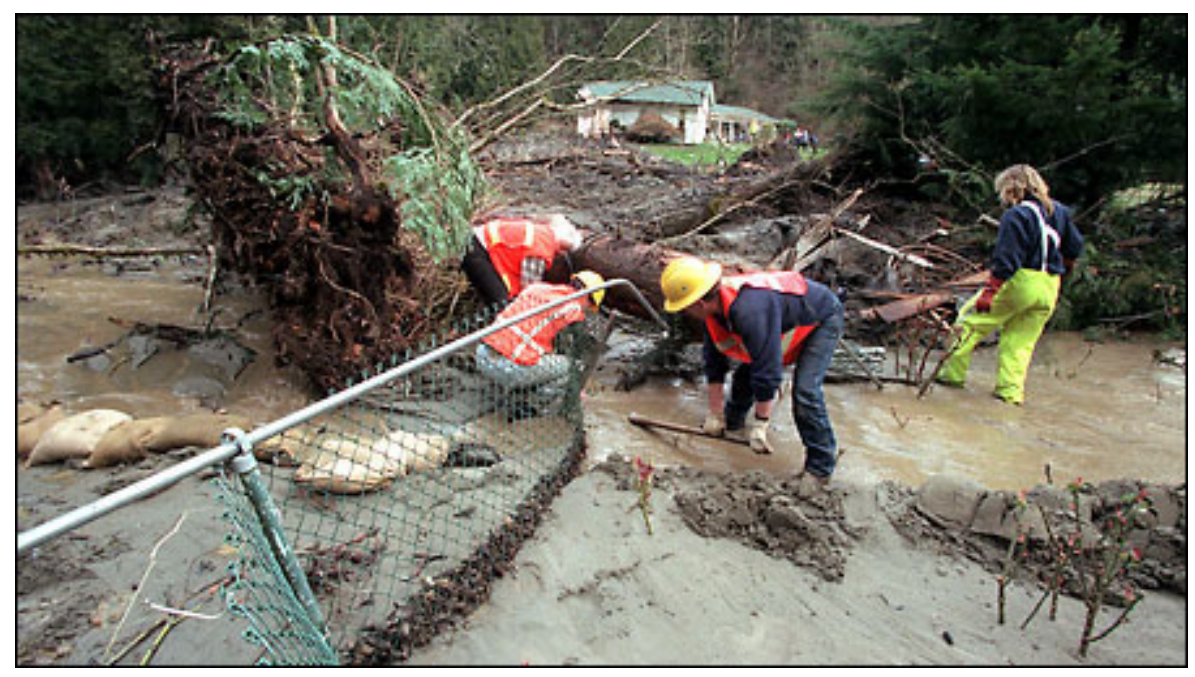

Figure 8-Cedar River landslide, near Renton (Photo courtesy of The Seattle Times).

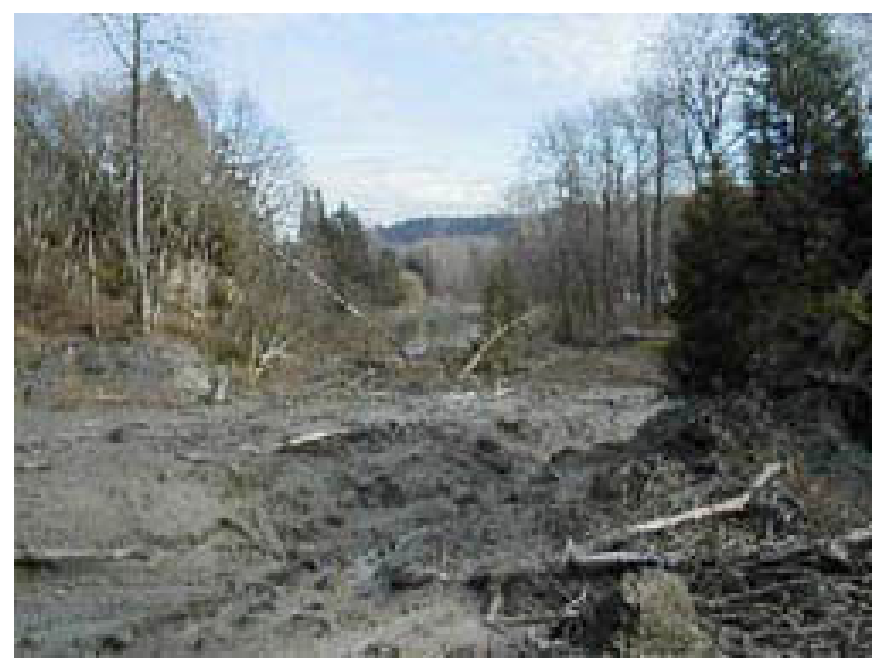

Figure 9-An additional landslide that blocked the Cedar River and caused flooding (Photo courtesy King County, Department of Natural Resources and Parks, February, 2001). 


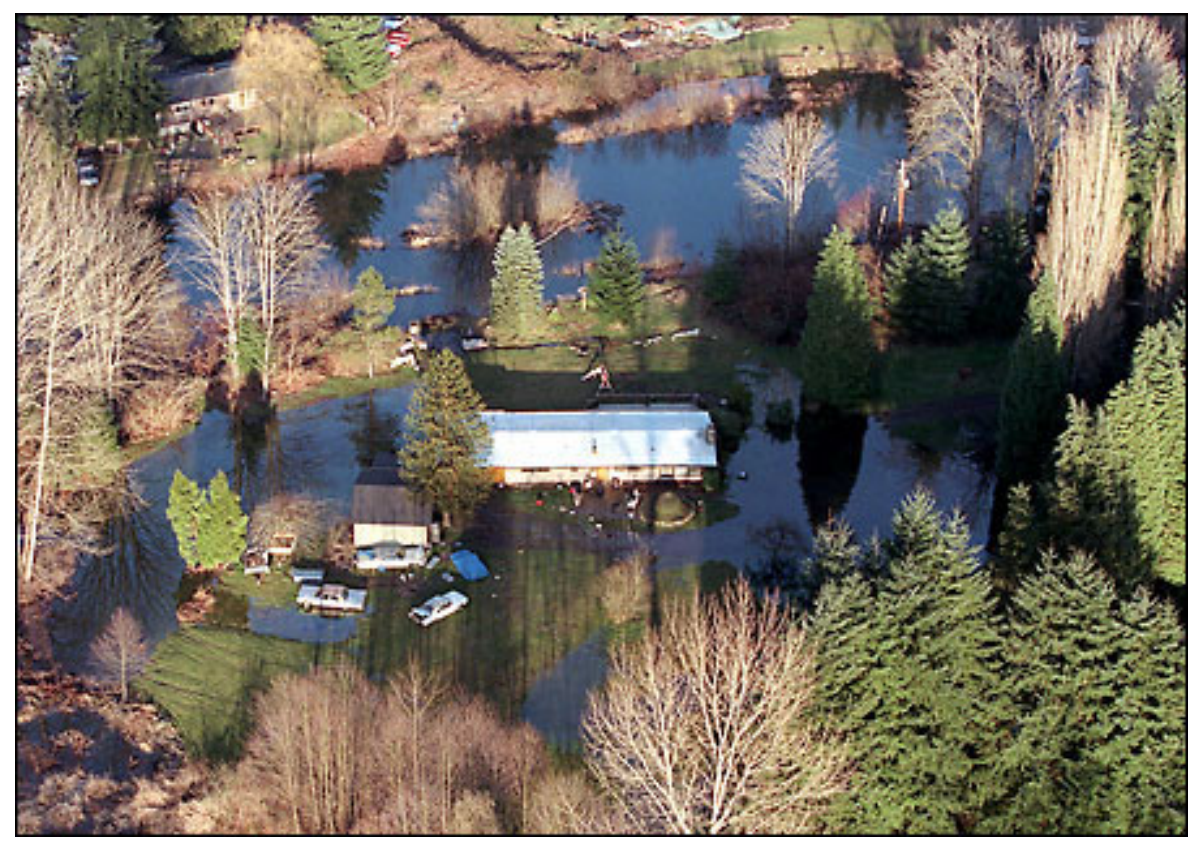

Figure 10-Aerial view of flooding caused by landslide that partially dammed the Cedar River (Photo courtesy King County, Washington, February, 2001).

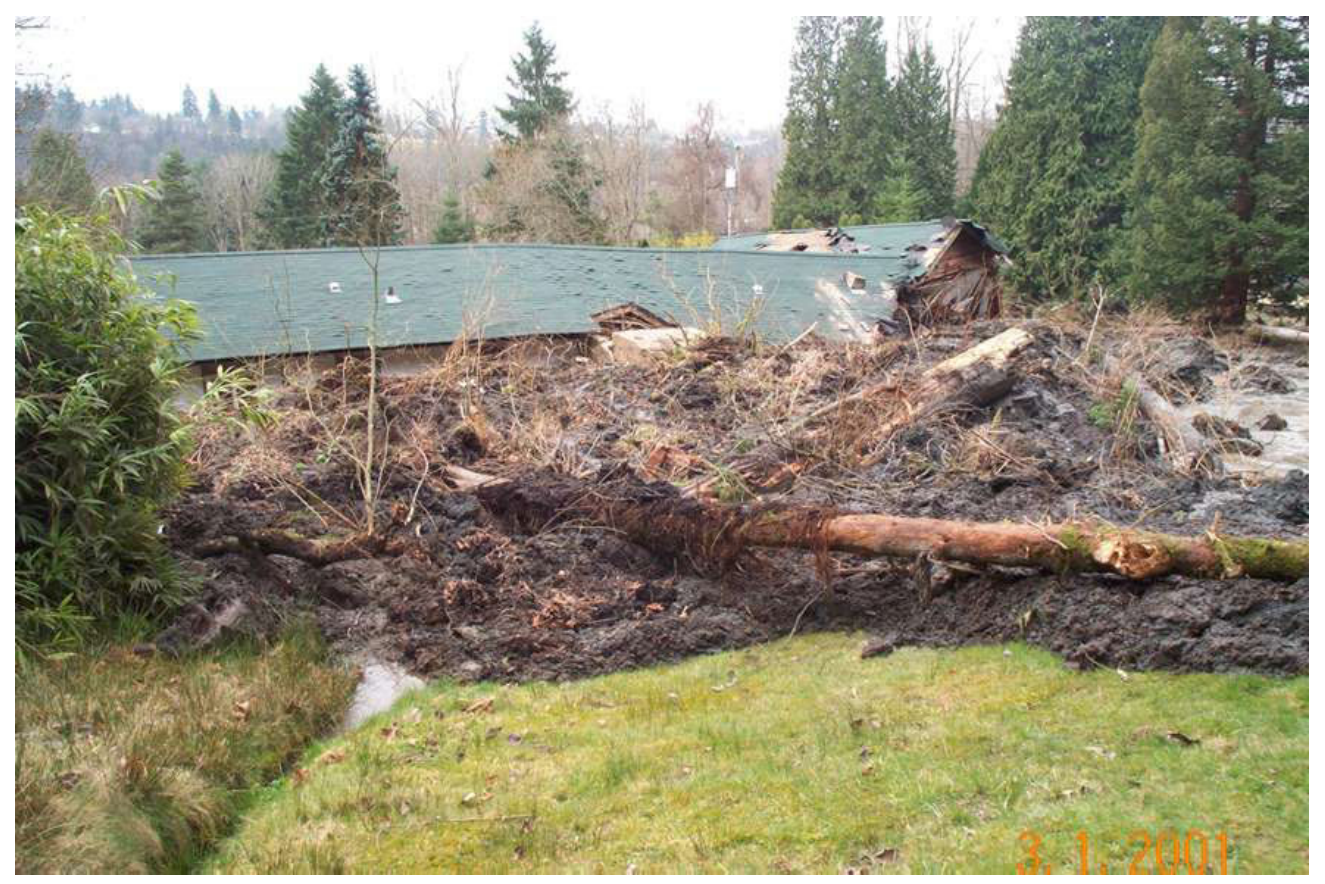

Figure11-House damaged by landslide along Cedar River-landslide deposits are at the center of the photo (Photo courtesy of King County, Washington, February, 2001). 


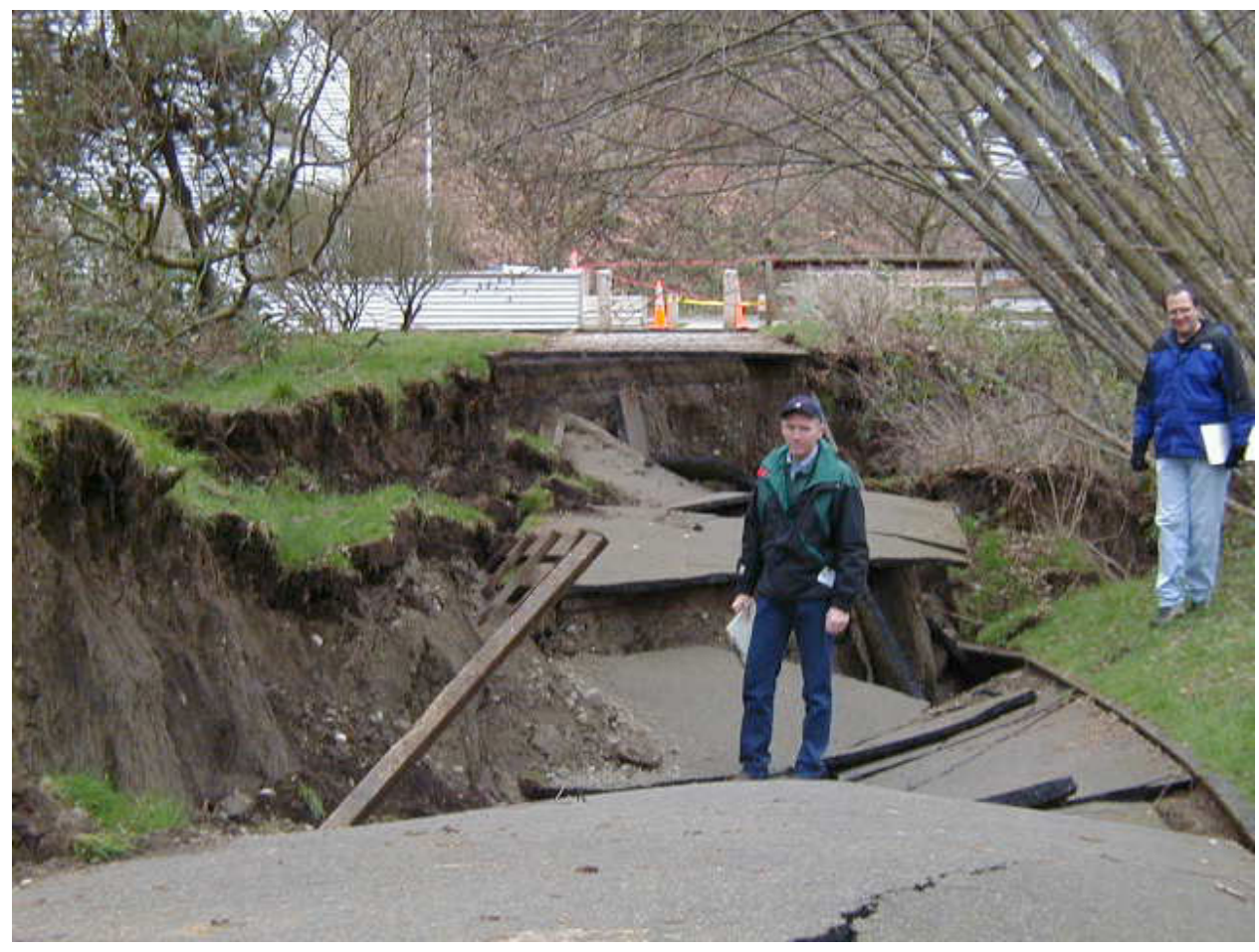

Figure 12-Capitol Lake, Olympia, landslide damage (Photo courtesy of WSDOT, February, 2001). 


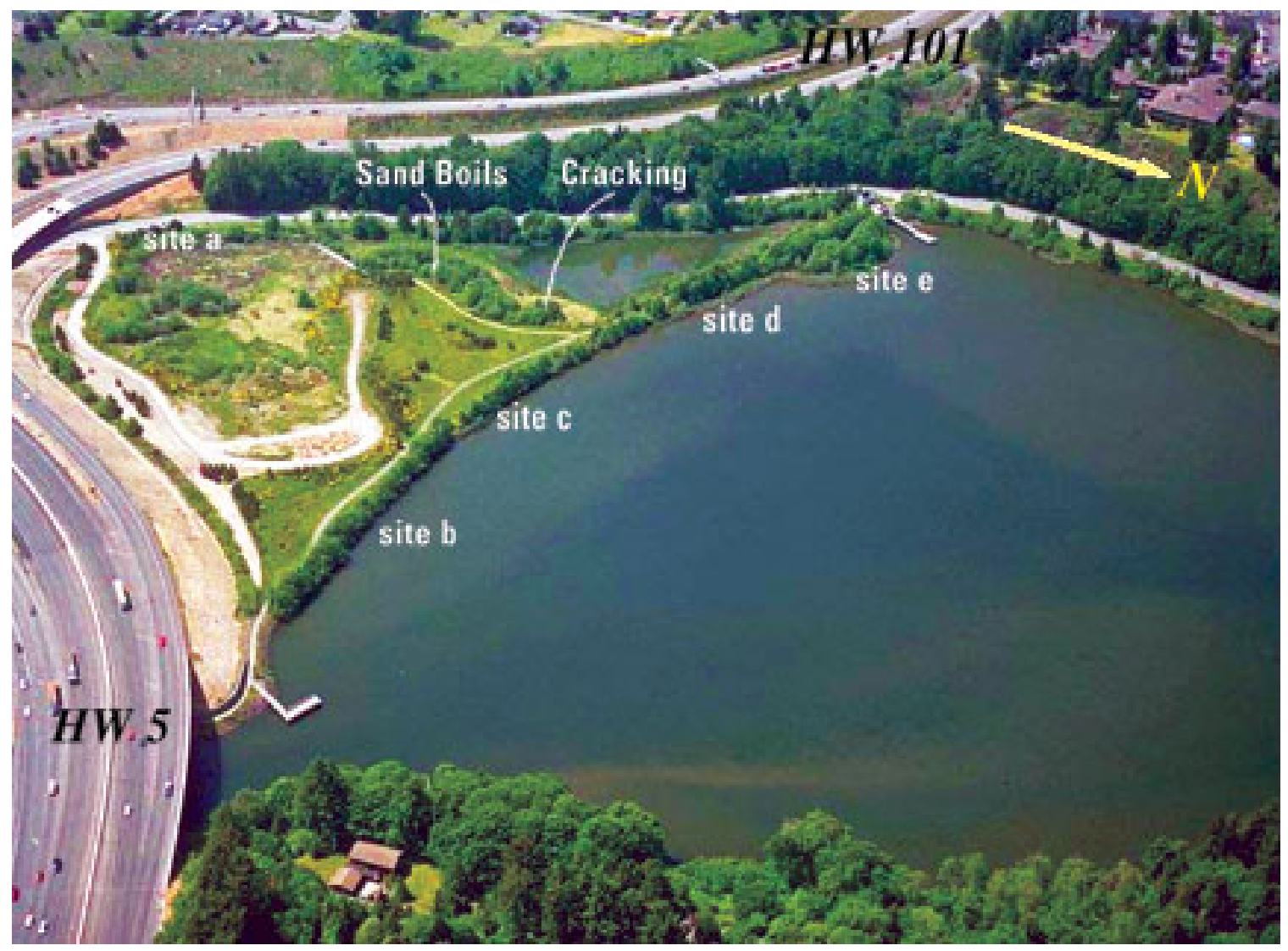

Figure 13-Slope failures/lateral spreads - Capitol Interpretive Center, near the Deschutes Parkway, Olympia (Photo from Bray and others, 2001). Figures 14 through 18 show close-up photos of damage at each lettered site (a through e) indicated here. 


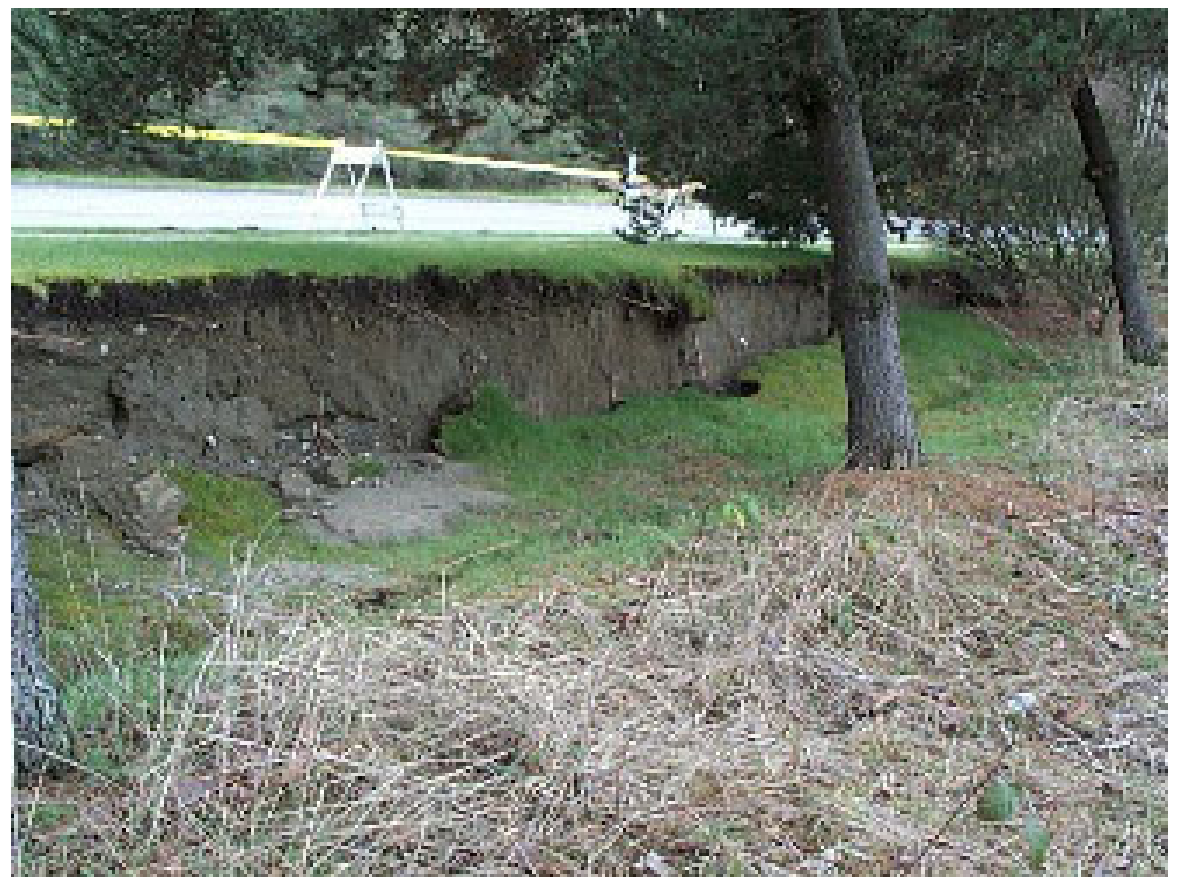

Figure14-Site a, Figure 13-Headscarp of lateral spread showing remains of sand boil (after heavy rain). The total length of the scarp is approximately 200 feet $(60 \mathrm{~m})$ with a maximum vertical drop of 3 feet $(1 \mathrm{~m})$ (Photo from Bray and others, 2001). 


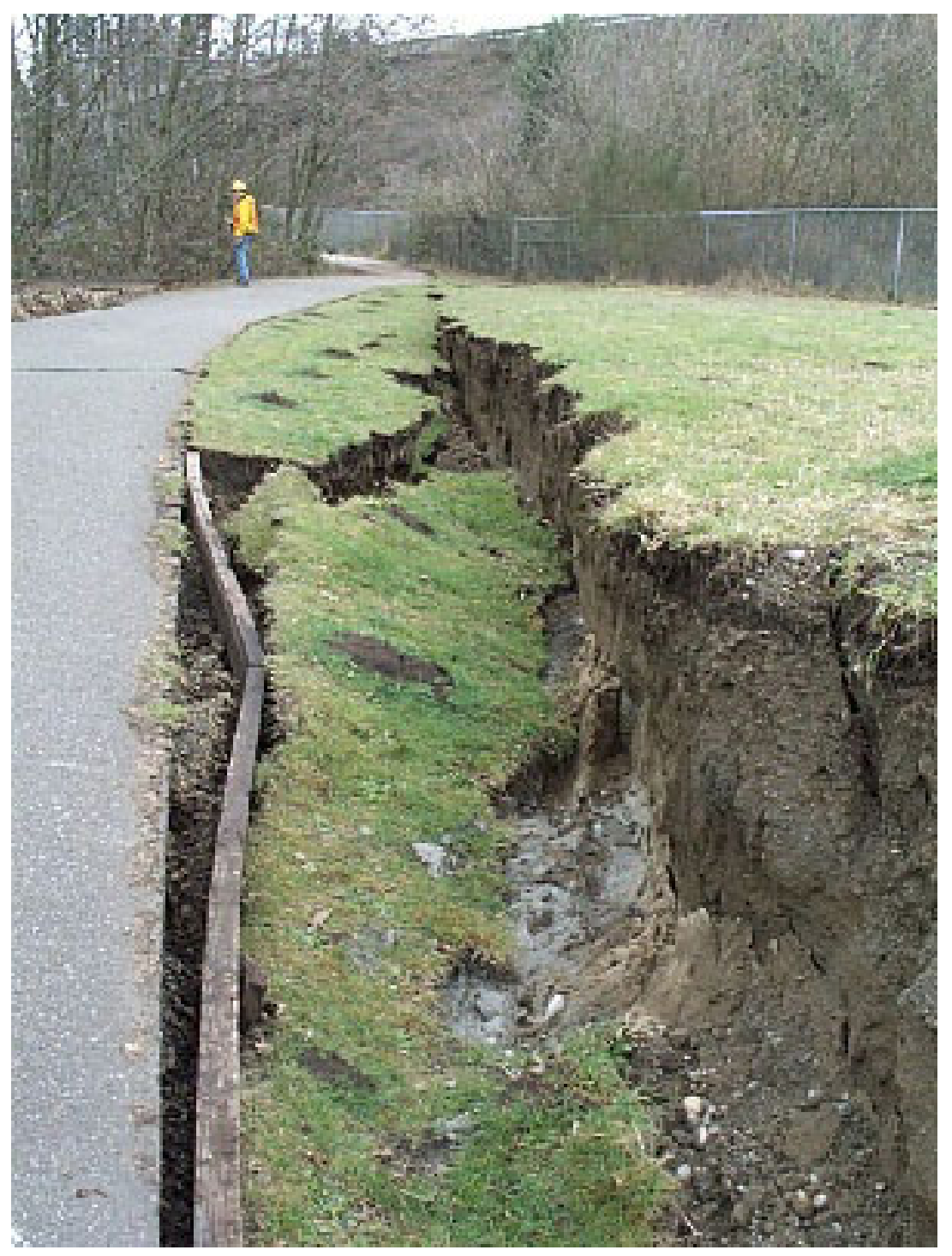

Figure 15-Site b, Figure13-Lateral spread of embankment

at Capitol Interpretive Center (Photo from Bray and others, 2001). (GPS location: N47.04270 ${ }^{\circ} \mathrm{W} 122.91090^{\circ}$ ). 


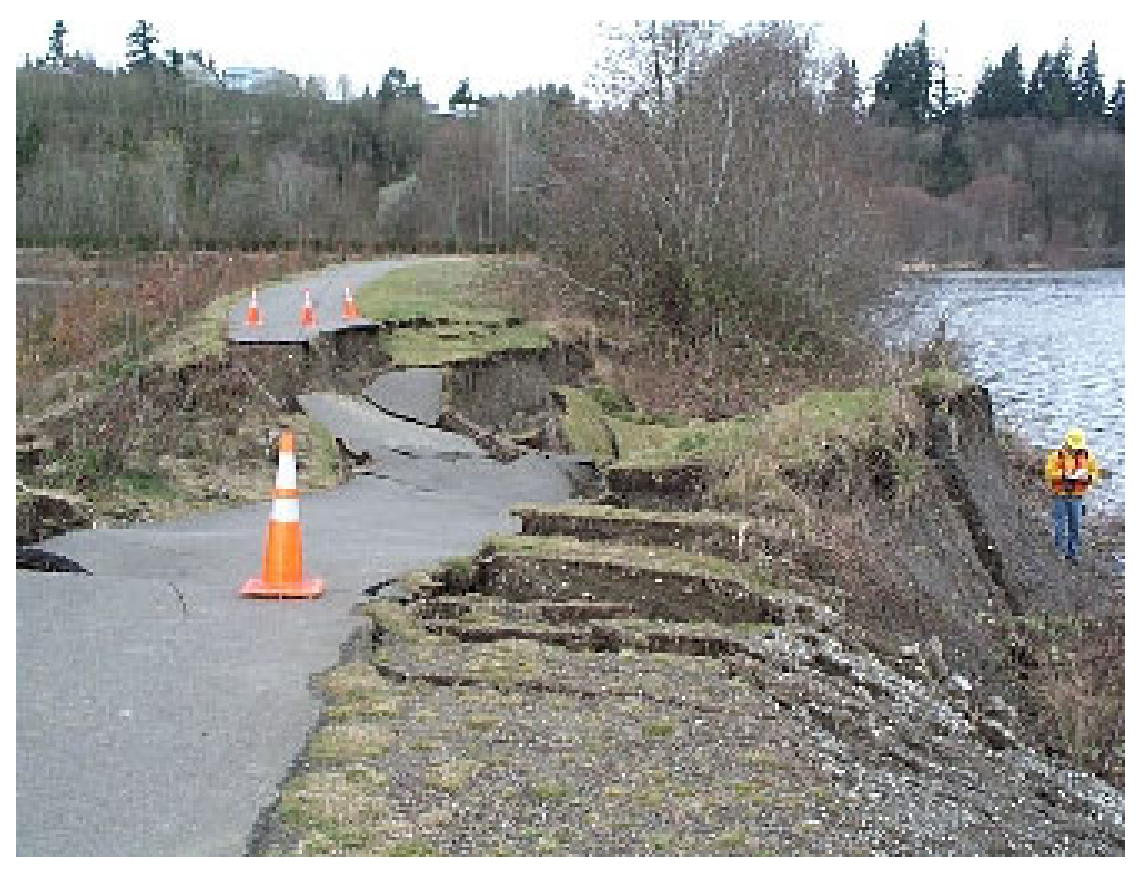

Figure 16-Site c, Figure13-East-to-west view of lateral spread of embankment at Capitol Interpretive Center. The length of the damage is approximately 75 feet $(225 \mathrm{~m}$ ) (Photo from Bray and others, 2001). (GPS location: N47.02396 ${ }^{\circ}, \mathrm{W} 122.90660^{\circ}$ ).

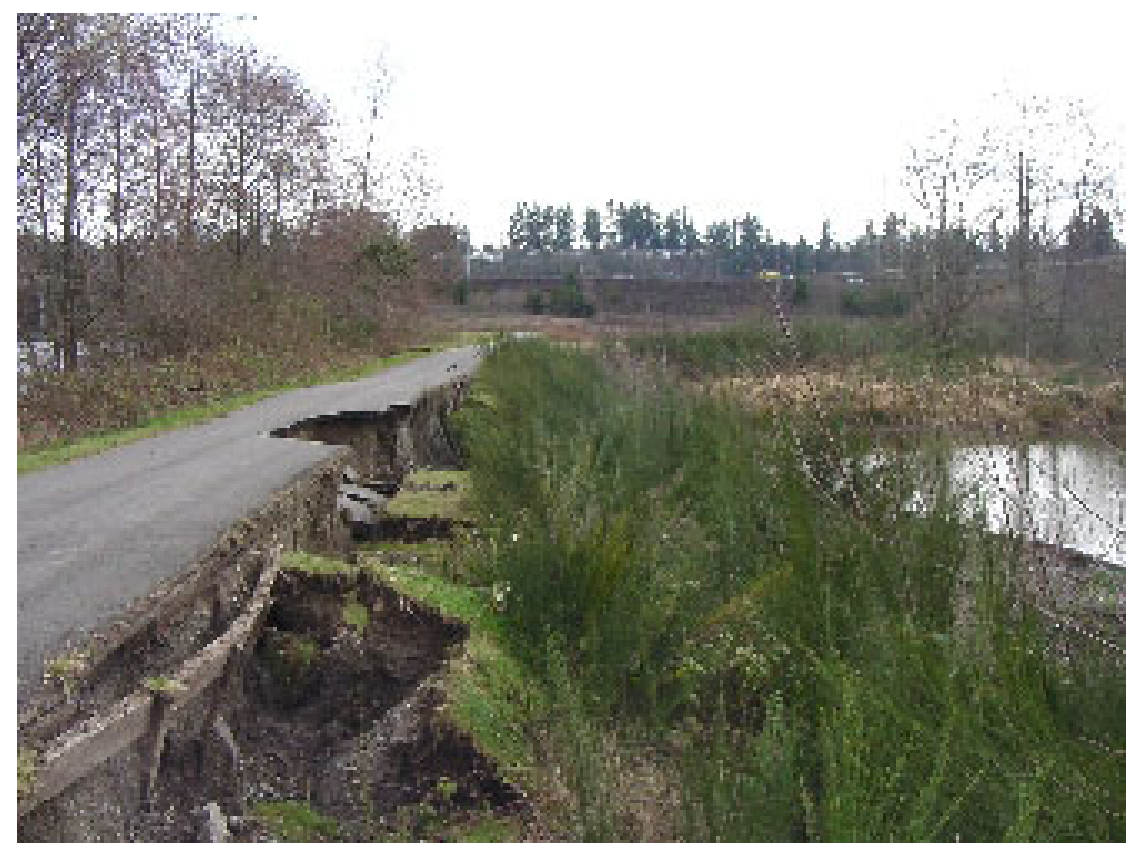

Figure17-Site d, Figure13-East-to-west view of embankment failure (lateral spread) at Capitol Interpretive Center (Photo from Bray and others, 2001). (GPS location: N47.02447 , $\left.\mathrm{W} 122.90784^{\circ}\right)$. 


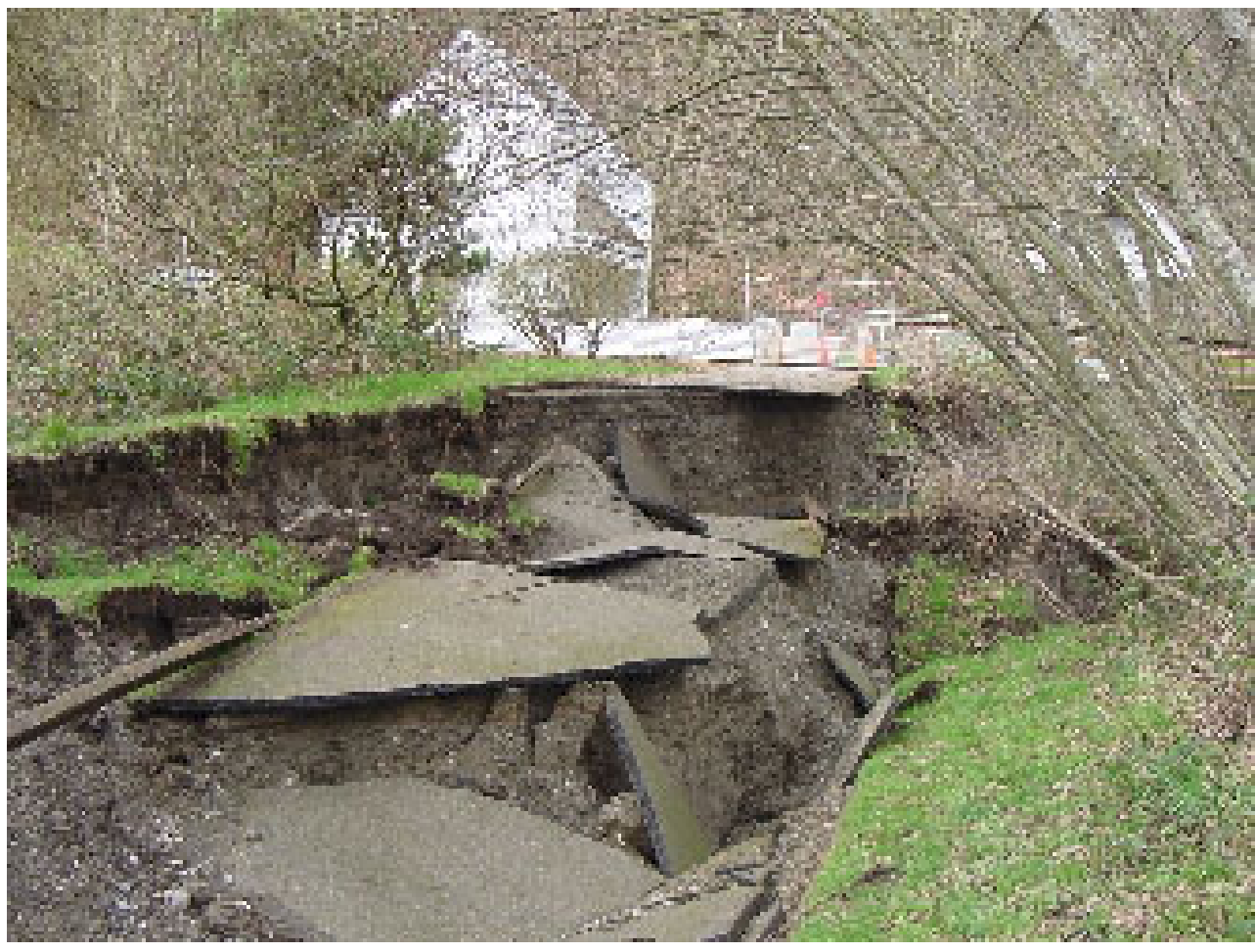

Figure 18-Site e, Figure 13-Failure of embankment due to liquefaction and lateral spreading at Capitol Interpretive Center (Photo from Bray and others, 2001). (GPS location: N47.02525 ${ }^{\circ}$, W122.91000). 


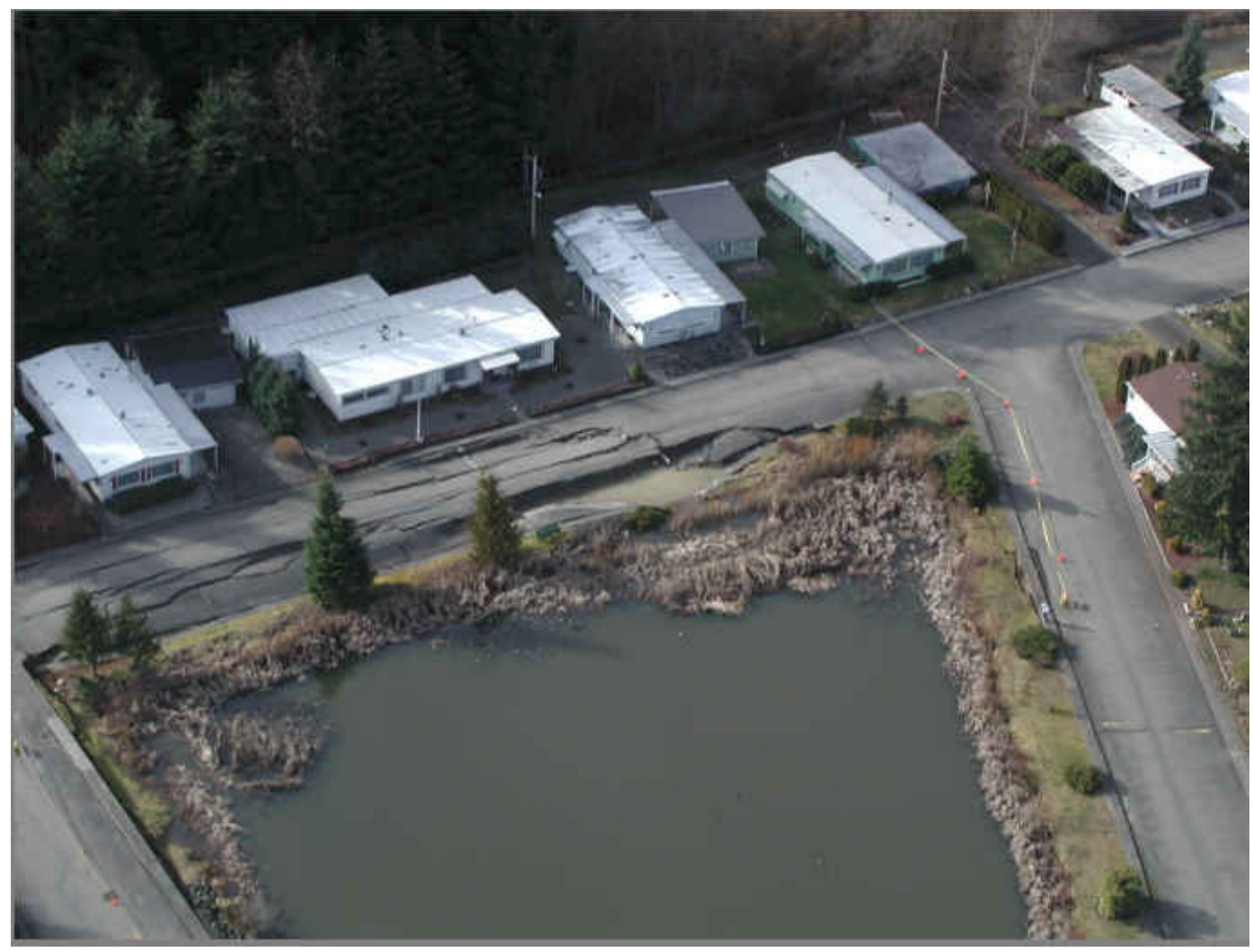

Figure 19-Aerial view of the lateral spread that occurred along a perimeter road of Sunset Lake, near Tumwater. The street affected by the flow is roughly aligned north-south where north is toward the bottom right corner of the photo (Photo from Bray and others, 2001). 


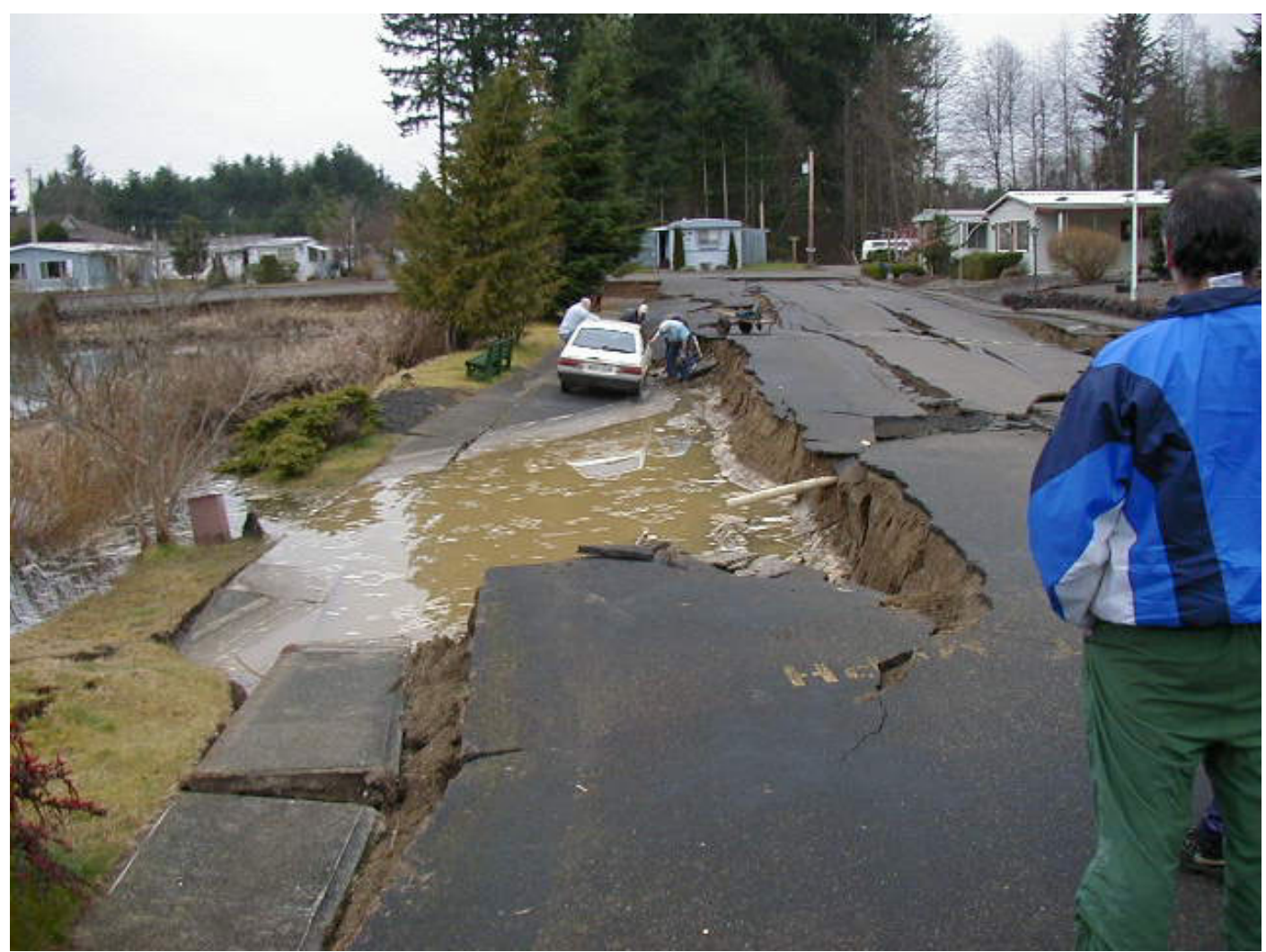

Figure 20-Close-up view of road failure at Sunset Lake, near Tumwater (Photo by Steven Kramer, University of Washington, Seattle). 


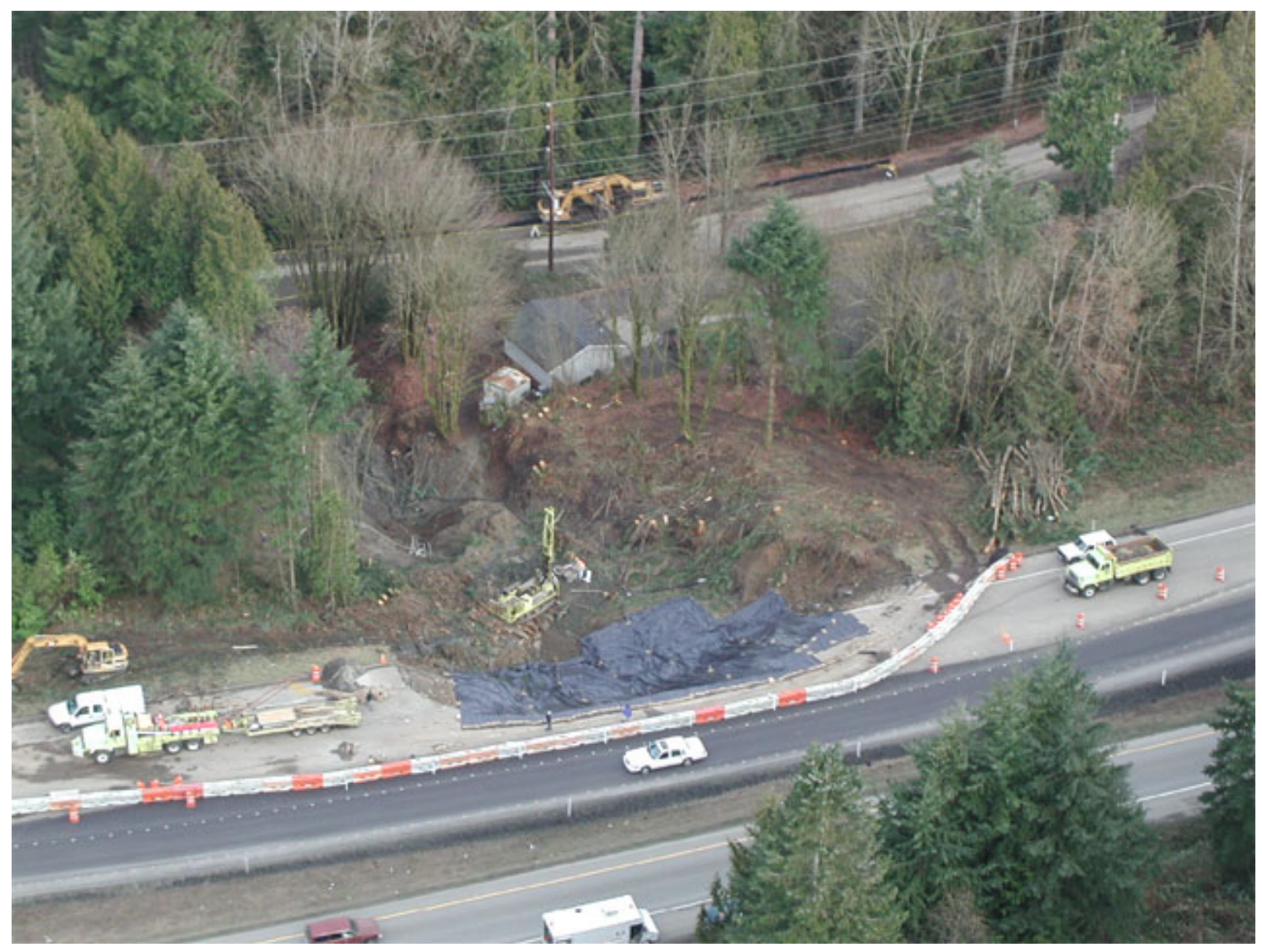

Figure 21-Landslide in U.S. Highway 101 road embankment near State Road (SR) 8 junction, northwest of Olympia. The earth embankment crosses a ravine that was carrying water at the time of the earthquake. The failed material moved down slope approximately $150 \mathrm{~m}$ and partially covered the road that parallels U.S. Highway 101 to the north (Photo from Bray and others, 2001) (GPS location: N47.05834º $\mathrm{W} 123.01365^{\circ}$ ). 


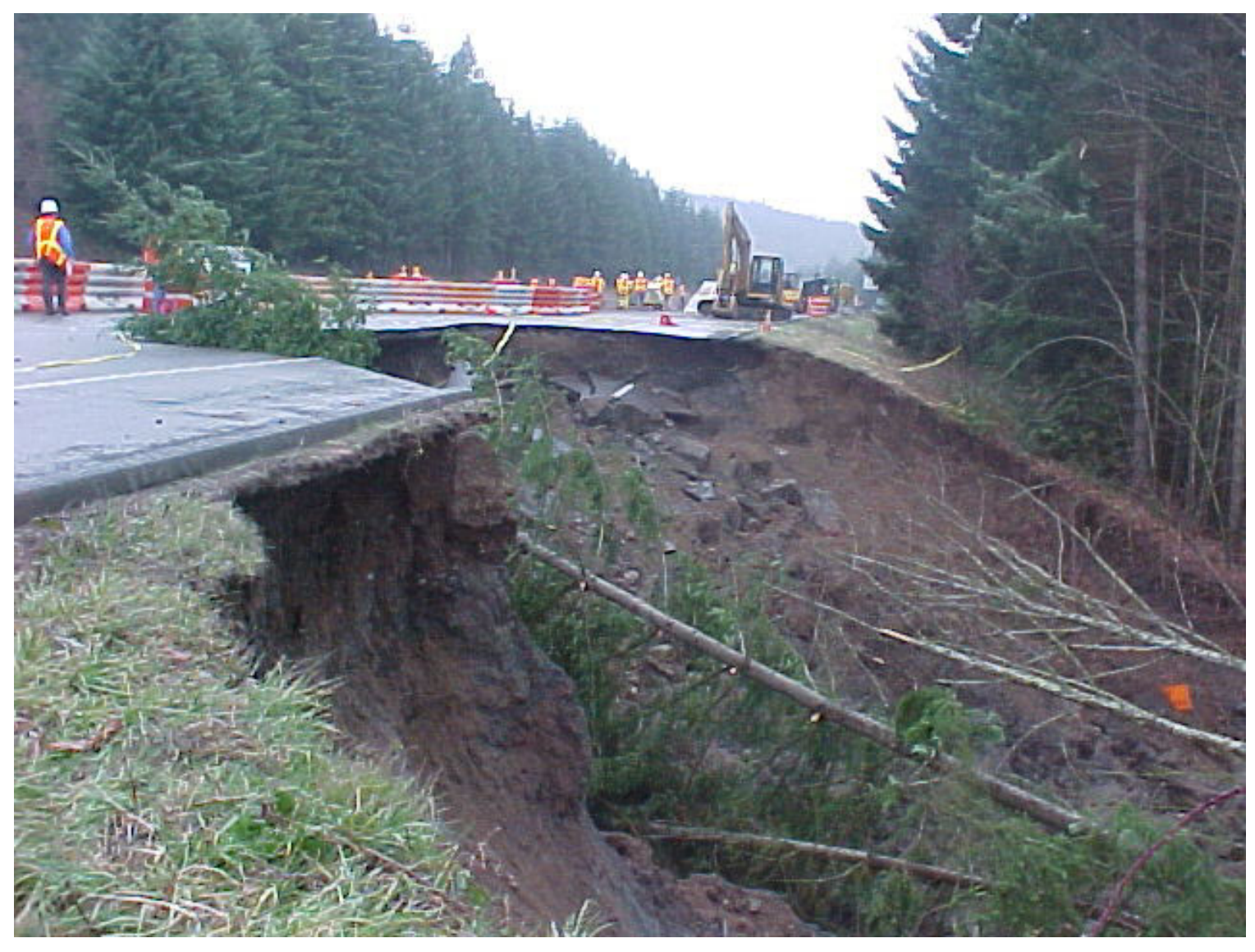

Figure 22-Close-up of U.S. Highway 101 landslide. The curved headscarp of the landslide is $24 \mathrm{~m}$ wide, and the total width of the landslide at the edge of the road is $35 \mathrm{~m}$ (Photo from Bray and others, 2001) (GPS location: N47.05834, W123.01365º. 


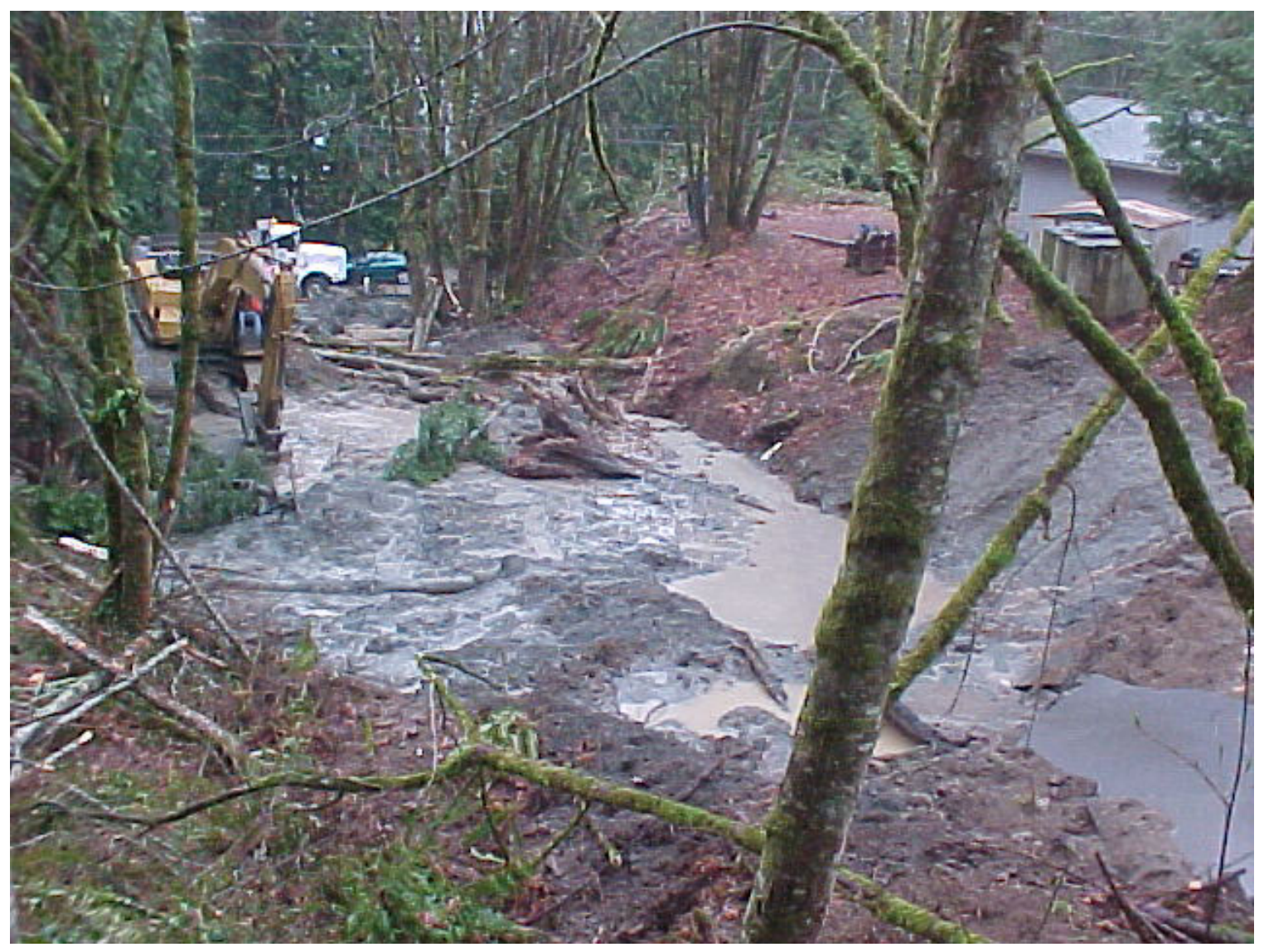

Figure 23.--View of runout of material down slope from the U.S. Highway 101 earth embankment landslide (Photo from Bray and others, 2001) (GPS location: N47.05834 ${ }^{\circ}$, $\mathrm{W} 123.01365^{\circ}$ ). 


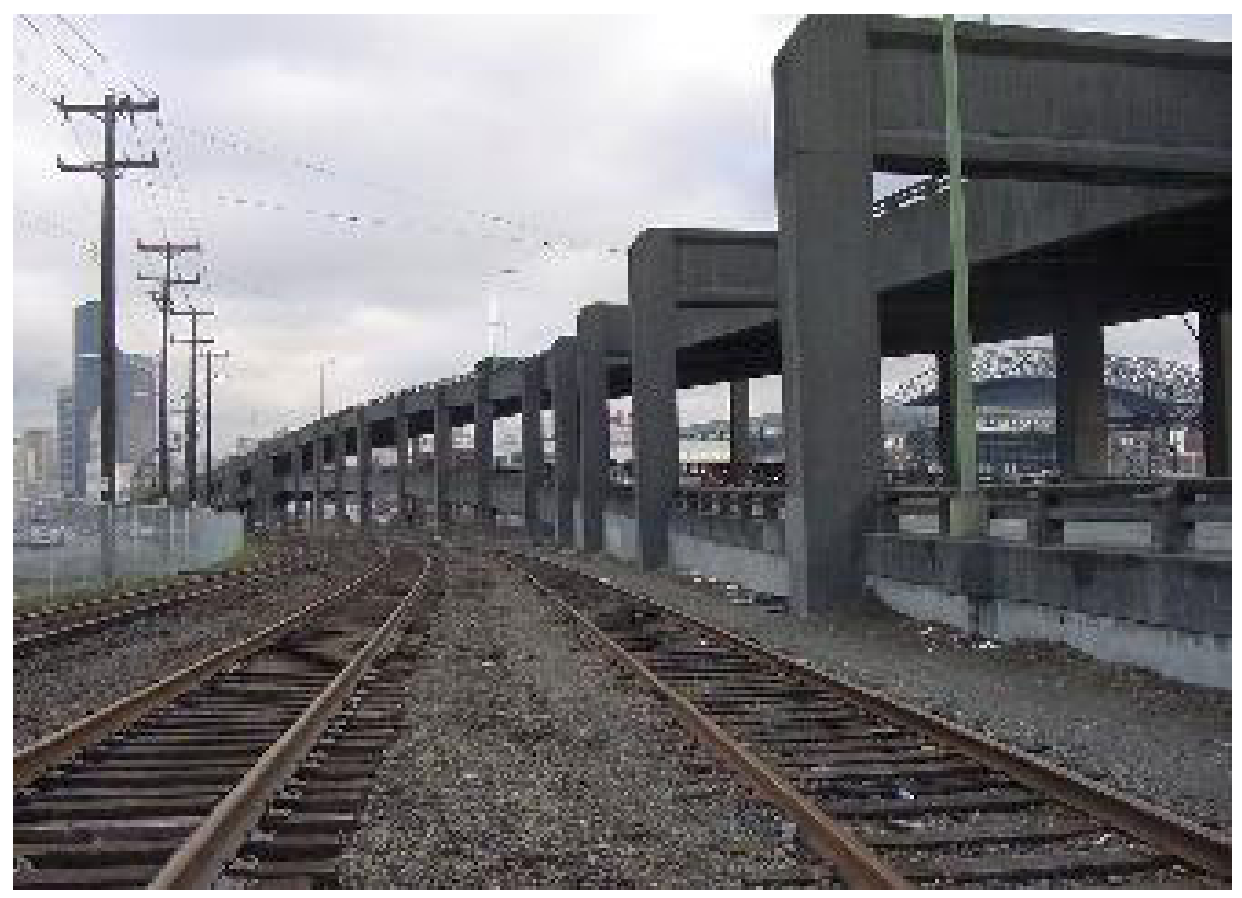

Figure 24-Photo of the Alaskan Way Viaduct, Seattle, showing location of point at which northern boundary of observed liquefaction occurred (Photo by Bray and others, 2001). 


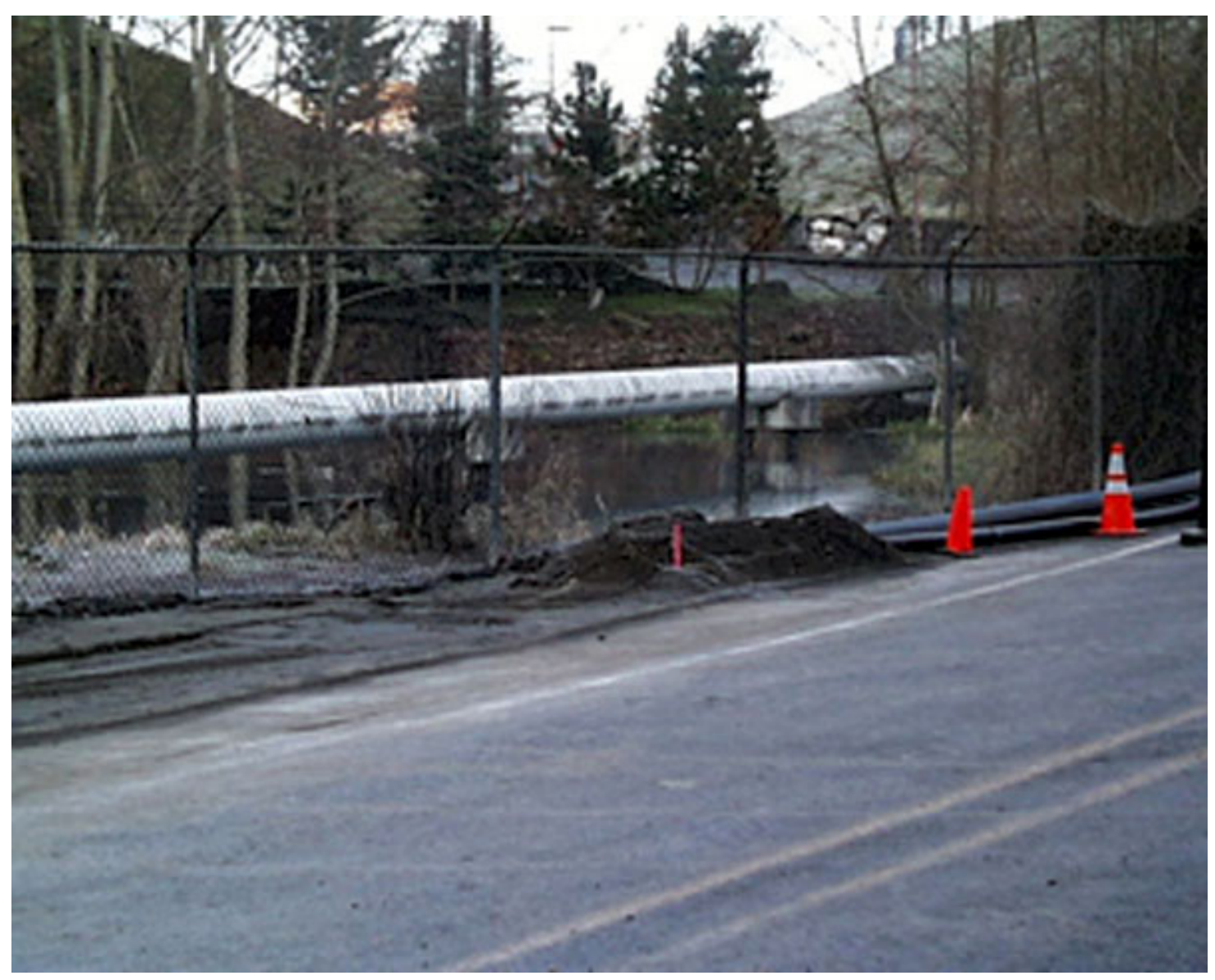

Figure 25-Chambers Road embankment failure and landslide. Sewer line repair using high-density polyethylene. Water-distribution line (undamaged) crosses adjacent to the bridge. Behind the water line on the far bank is a small landslide with several trees within sliding block (Photo by Bray and others, 2001) (GPS location: N47.1917º, $\left.\mathrm{W} 122.5733^{\circ}\right)$. 


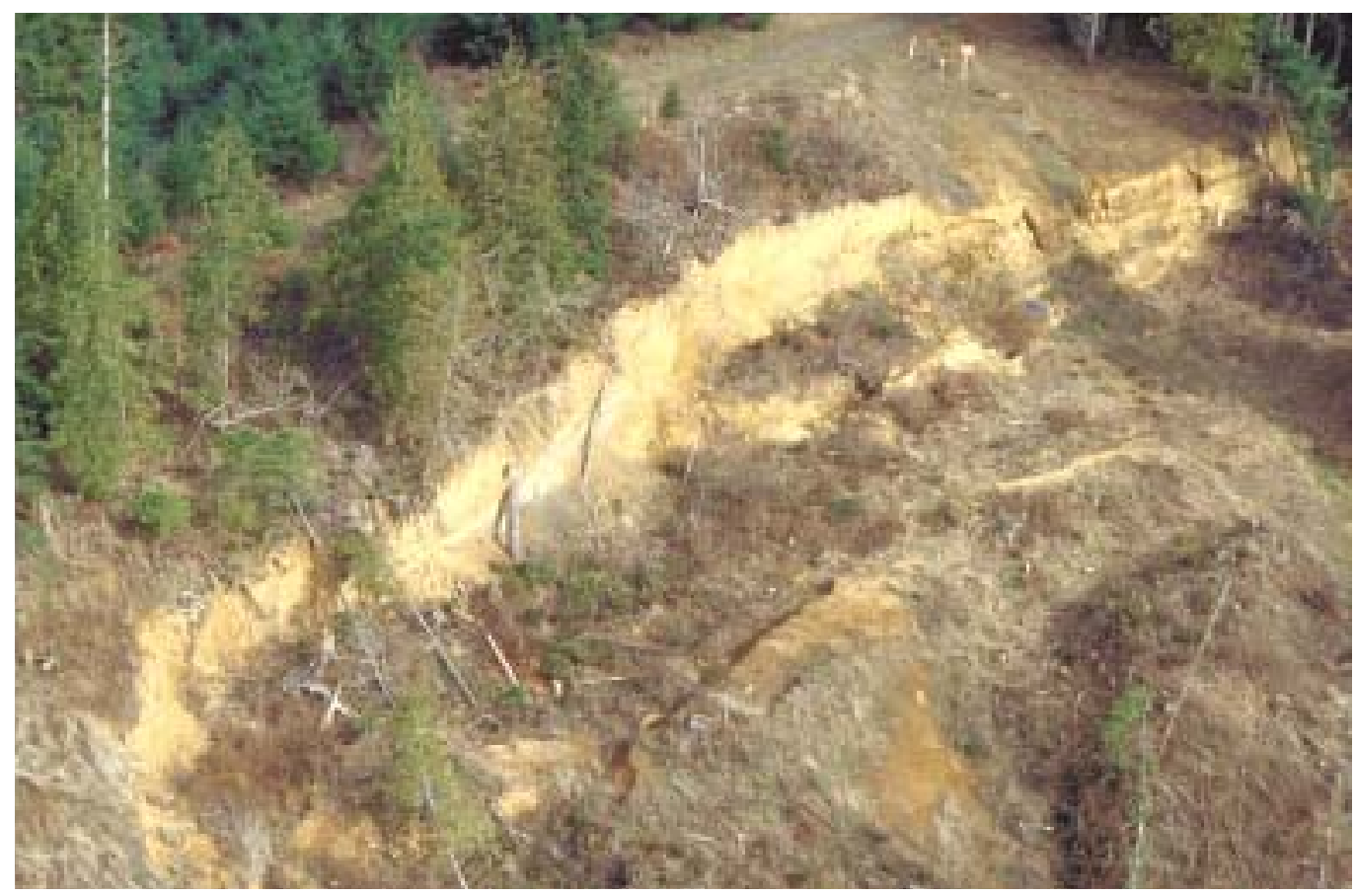

Figure 26-Photo of pipeline slide near Null's Crossing (Lewis County), near

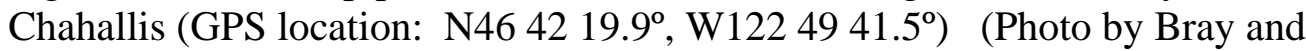
others, 2001).

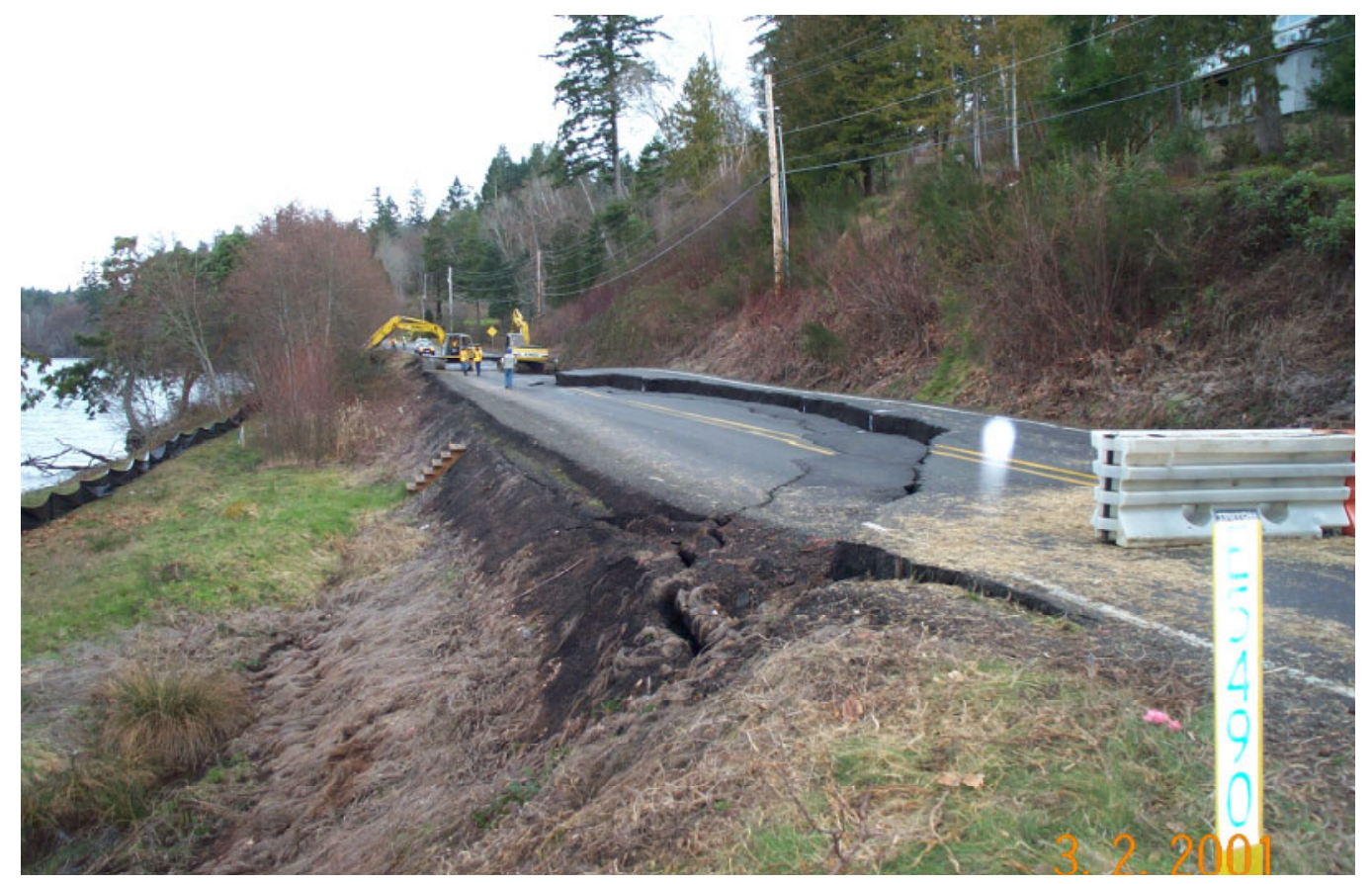

Figure 27-Victor Fill area landslide, near Port Orchard (Photo by Ed Harp, U.S. Geological Survey). 